\title{
On the Origin of Indian Logic from the Viewpoint of the Pāli Canon
}

\author{
Andrew Schumann
}

\begin{abstract}
In this paper, I show that in the Pāli Canon there was a tradition of Buddhist logic, but this tradition was weak, and the proto-logic we can reconstruct on the basis of the early Pāli texts can be evaluated as a predecessor of the Hindu logic. According to the textual analysis of the Pāli texts, we can claim that at the time of the closing of the Pāli Canon (excluding the later addition of the Milindapañha into it by the Burmese tradition) there did not exist the Nyāya philosophy known by the Nyāya Sütra. Meanwhile, we can assume that the Milindapañha, the best logical source of early Pāli literature, was written under influences of the Gandhāran Buddhists and this text preceded the Nyāya philosophy.

Mathematics Subject Classification. Primary 03A05; Secondary 03B65, 03B05, 03B22.
\end{abstract}

Keywords. Theravāda, Pāli Canon, Kathāvatthu, Milindapañha, Buddhist logic, Greco-Buddhism, nyāya.

\section{Introduction}

This paper provides an argument supporting the claim that the authors of the Pāli Canon and Milindapañha did not know about the Nyāya school of logic and knew nothing about syllogisms defined in the Nyāya Sūtra (Sect. 2). The methodology for this conclusion is discussed in Sect. 3 .

The argument is focused on the following claims: (i) the terms denoting logic (such as nyāya) and occurring in the Pāli Canon were not used, in accordance with their contextual meanings, to denote the school of logic or the Nyāya Sūtra (Sect.4); (ii) in some early Pāli suttas some terms denoting logical reasoning have sometimes negative connotations (Sect.4), nevertheless in the Theravāda tradition there are many explanations why we need logic still; (iii) in the Pāli Canon, the terms like nyāya have the meaning of the method of Buddhists distinguishing them from non-Buddhists (Sect.4); (iv) it seems that in the Pâli texts there are a few logical syllogisms used for the 
logical purpose, but the majority of syllogisms are used without understanding of their logical nature, they are rather used for the purpose of rhetoric, e.g. syllogisms often play a rhetorical role in the Kathāvatthu (Sect. 5); (v) so, the author of the Kathavvatthu had no good competence in symbolic (systematic) logic, because there are a lot of sophisms and other fallacies among correct syllogisms (Sect.5); (vi) in the Kathâvatthu and in other Abhidhamma texts there is no requirement to give examples in syllogisms - but it is one of the principal requirements of the Nyāya tradition as well as the Yogācāra logic (Sect. 5); (vii) the author(s) of the Milindapañha (its historical context is considered in Sect.6) did have a good competence in symbolic logic, e.g. there are no sophisms and we face a requirement here to give examples for verifying statements - this requirement is explained in the text in a more primitive way terminologically than it was done in the Nyāya Sütra, hence this text preceded the Nyāya philosophy and can have had an impact on the latter (Sect. 7).

Taking into account the genesis of logical knowledge in early Pāli literature from (i) to (vii) we can assume that the Gandhāran (Greco-Buddhist) influence on the origin of Indian systematic logic is highly possible and at least not excluded if we concentrate just on the Pāli texts. In order to infer this statement, the Mill's joint method of agreement and difference is applied ${ }^{1}$ :

On the one hand, the Milindapañha is the only early Pāli source in which we deal with a proto-Nyāya logic - it is a main feature of this text to be logical among all other canonical texts, and, on the other hand, the Milindapañha was written in Gandhāra, the region where the Greek language was official for 300400 years at least (e.g. it was used for edicts, business documentation, courts, and taxation as lingua franca) and the Hellenistic influences on social life here were evident. Thus, the early Buddhist knowledge of systematic logic is supposed to be not connected to the Nyāya Sūtra, but can have been established under a Hellenistic (Gandhāran) influence.

Formally:

The canonical texts, such as the Yamaka, the Kalahavivāda-sutta (Sutta-nipāta 4.11), the Kathāvatthu, and the Milindapañha, deal with syllogisms;

The Yamaka deals with a converse of implications (reversing its two parts);

\footnotetext{
1 There are the following five methods of induction introduced by philosopher John Stuart Mill in the book A System of Logic (1843): direct method of agreement, method of difference, joint method of agreement and difference, method of residue, and method of concomitant variations. These methods give us the best way of modelling the historical reality on the basis of scattered archeological and textological data. In this paper, my conclusions follow these methods. One of the possible schemata for the joint method of agreement and difference is as follows:
}

$A, B, C$ occur together with $x, y, z$;

$A, D, E$ occur together with $x, v, w$;

$B, C$ occur with $y, z$;

Therefore $A$ is the cause, or the effect, or a part of the cause of $x$. 
The Kalahavivāda-sutta deals with a transitivity of implications (combining several implications having a joint part);

The Kathāvatthu deals with modus ponens and modus tollens;

The Milindapañha deals with modus ponens and modus tollens;

The Yamaka, the Kalahavivāda-sutta, and the Kathāvatthu do not provide syllogisms with a Nyāya or proto-Nyāya way of verifying premises;

The Milindapañha provides syllogisms with a proto-Nyāya way of verifying premises;

The Yamaka, the Kalahavivāda-sutta, and the Kathāvatthu use sophisms and combine correct and incorrect syllogisms;

The Milindapañha does not use sophisms and applies only correct syllogisms;

The Milindapañha is, perhaps, the only early Pāli text written in Gandhāra by, one expects, a direct Hellenistic or Gandhāran (GrecoBuddhist) influence;

Therefore, probably, the correct application of inference rules in the early Buddhist logic is explained by a Hellenistic or Gandhāran (Greco-Buddhist) influence. ${ }^{2}$

Notice that the Mill's joint method of agreement and difference I have applied in this paper is not deductive, but plausible with a high probability.

Hence, I have performed an experiment as a logician to check the logical culture of ways of using syllogisms in the Pāli Canon and, as a consequence of my experiment, I am probabilistically concluding that the authors of the early Pāli texts did not know the Nyāya Sütra. It means that on the basis of the corpus of these texts we can claim that at the time of the authors of the early Pāli texts (until the 1st century A.D. or even later) the Nyāya school of logic did not exist yet. (According to some other data the Nyāya Sütra

\footnotetext{
${ }^{2}$ Formally, a very short version:

$Y$ (Yamaka), Kl (Kalahavivāda-sutta), Kt (Kathāvatthu), M (Milindapañha) occur together with $x$ (correct applications of inference rules) and $y$ (incorrect applications of inference rules);

$M$ as the only Pāli text from Gandhāra occur together with $x$ (correct applications of inference rules) and $z$ (proto-nyāya doctrine on verification premises) and without $y$ (incorrect applications of inference rules);

$Y$ (Yamaka), Kl (Kalahavivāda-sutta), Kt (Kathāvatthu) occur with $y$ (incorrect applications of inference rules) and without $z$ (proto-nyāya doctrine on verification premises);
}

Therefore $M$ as the only Pāli text from Gandhāra is the cause, or the effect, or a part of the cause of $x$ and $z$. In other words, to be Gandhāran is the cause, or the effect, or a part of the cause of $x$ and $z$. 
is dated not earlier than the 2nd century A.D. too, e.g. there are quotings in this sūtra from some early Madhyamaka and Yogācāra texts dated to this century or later and written probably in Gandhāra, too - their early fragments in Gāndhārī are excavated in this area).

\section{Problem Setting}

The following presuppositions are the most principal for any system of symbolic logic:

(i) Each proposition should be factual and, then, it is either true or false. It is true if it correctly describes an appropriate fact, otherwise it is false. For example, the proposition 'it's raining' is true if it's raining now indeed in a specified place.

(ii) Into our reasoning we can involve only true propositions.

(iii) There are logical schemata that are called inference rules and they infer only true propositions from true premises. Hence, our conclusions are ever true if we apply inference rules in relation to true premises.

In symbolic logic the following two inference rules are fundamental:

(1) Modus ponens. Let $A$ and $B$ be two factual propositions. Assume that ' $A$ implies $B$ ' and $A$ are both asserted to be true. Then we can draw the conclusion that $B$ must be true, too. Symbolically:

$A \Rightarrow B$ is true; $A$ is true.

Then $B$ is true, also.

$(A \Rightarrow B) ; A$

$B$.

(2) Modus tollens. Let $A$ and $B$ be two factual propositions again. Suppose, ' $A$ implies $B$ ' is considered true, but it is not the case that $B$. Then we can draw the conclusion that it is not the case that $A$, too. Symbolically: $A \Rightarrow B$ is true; $B$ is false.

Then $A$ is false, also.

$(A \Rightarrow B) ; \neg B$

$\neg A$.

In the Old-Greek philosophy, the above presuppositions (i)-(iii) were widely accepted due to the logical works written by Aristotle (384-322 B.C.) and Chrysippus (ca. 279-ca. 206 B.C.). In the meanwhile, Aristotle proposed a modification of modus ponens and modus tollens for categorical propositions and Chrysippus formulated modus ponens and modus tollens conventionally in the way as said above.

Hence, if we can observe that someone understands presuppositions (i)(iii) and can follow them in his/her reasoning, then he or she possesses a good logical competence. This competence is detected in the Nyāya as well as in the Madhyamaka and Yogācāra texts. Certainly, the Nyāya Sūtra was one of the 
first Indian documents, whose author(s) possessed a good logical competence. In particular, the author(s) of the Nyāya Sütra accepted presuppositions (i)(iii) of symbolic logic. He explicitly pointed out that we cannot cast doubt, first, on factual propositions which are successfully verified (pratyaksa) and, second, on conclusions drawn correctly by means of inference rules from true premises (anumāna):

It is incongruous to attribute or deny what [has already become] the subject of perception or inference

dṛștānumitānām hi niyogapratiședhānupapattih (Nyāya Sūtra 3.1.51).

In the Nyāya Sütra, we face many examples of correct applications of modus ponens and modus tollens. For instance, modus tollens is applied here:

$\bar{I}$ śvara is a reason for observing that human actions are fruitless. Wrong, because without human actions there is no "fruiting".

Not an argument - due to the conditionality of the latter.

iśvarah kāraṇam, puruṣakarmāphalyadarśanāt ||19||

na, purușakarmābhāve phlānișpatteh $\|20\|$

tatkāritatvād ahetuh $\|21\|$

(Nyāya Sütra 4.1.19-21).

Formally: If the Lord ( $\bar{s}$ vara) is a cause $(A)$, then human actions are without fruits $(B)$. Nevertheless, they are ever with fruits $(\neg B)$. Then the Lord is not a cause $(\neg A)^{3}$ :

$$
(A \Rightarrow B) ; \neg B
$$

$\neg A$.

The Nyāya Sütra is dated very differently by differet scholars: from the 6th century B.C. to the 2nd century A.D. [23, p. 4]. Let us notice that the dating from the 6 th to the 5 th century B.C. is quite improbable from the archeological point of view. The matter is that at that time the Painted Grey Ware culture existed which is characterized by a very low-scale urbanization at the GangaYamuna valley. For instance, the settlements of this culture could be quite large, but they had no town planning and consisted of buildings made from bamboo and loam which can be compared to today's slums of Mumbaian unstructured housing and lack of infrastructure. There were no states as well as no cities in the strict sense. Therefore it is obvious why there was neither a writing system nor money. The large-scale urbanization began only since ca. 400 B.C. The śramana movement was a spiritual way to resist this urbanization - since that time it was just the very beginning of philosophical reflection of India in the pure meaning. Hence, we cannot date the Nyāya Sütra from the 6 th to the 5 th century B.C. certainly. It was a late-Vedic period without any sütras.

\footnotetext{
${ }^{3}$ It is worth noting that this phrase is so close to the Madhyamaka manner of refutation of God's existence and it can be taken from the Madhyamaka texts such as Iśvara-kartrtvanirākṛtih-viṣnnoh-ekakartṛtva-nirākaraṇa ascribed to Nāgārjuna.
} 
In any case, among different date patterns, the 2nd century A.D. is the most reasonable dating of the Nyāya Sütra from the standpoint of archeology. At that time in the Kuṣaṇa Empire there was observed a flowering of sciences and arts in India, the first big fruit yielded by the large-scale urbanization started from ca. 400 B.C. Textologically, there are also many arguments supporting this dating. So, these arguments are collected by Vidyabhusana [43] and they are as follows: (i) the Nyāya Sütra contains many quotes from some early Madhyamaka and Yogācāra texts which are dated to the 2nd century A.D. or even later; (ii) the Nyāya Sütra can be examined as a systematization of logical pieces from the Caraka-samhita dated to the same century.

(i) For instance, there are evidences that the author(s) of the Nyāya Sūtra accepts kșanikavāda (teaching on momentariness), a key doctrine of Yogācāra (as well as of the earlier Sautrāntika thought), e.g.:

There is no reason [to deny the difference] in the crystal, because, due to momentariness of [all], the particles [of the crystal] are updated one after the other.

sphațike api aparāparotpatteh ksạikatvāt vyaktīnām ahetuh (Nyāya Sütra 3.2.10).

There are many quotings from the Madhyamakaśāstra of Nāgārjuna. The verse: na svabhāvasiddhih, āpekșikatvāt (Nyāya Sūtra 4.1.39)

is used to express the madhyamaka doctrine and it is close to:

na hi svabhāvo bhāvānām pratyayādiṣu vidyate |

avidyamāne svabhāve parabhāvo na vidyate ||5|| (Madhyamakaśāstra $1: 5)$.

The next passage to show the Madhyamaka doctrine is as follows:

nāsanna sanna sadasat, sadasatorvaidharmayāt (Nyāya Sūtra 4.1.48)

It is similar to the following verse:

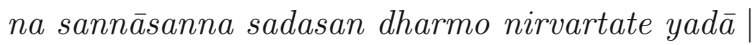

katham nirvartako heturevam sati hi yujyate ||9|| (Madhyamakaśāstra $1: 9)$.

The doctrine of Madhyamaka and Yogācāra is exemplified as follows: māyāgandharvanagaramrgatṛṇikāvadvā (Nyāya Sūtra 4.2.32)

This example is taken from the following verse:

yath $\bar{a}$ māy yath $\bar{a}$ svapno gandharvanagaram yath $\bar{a} \mid$

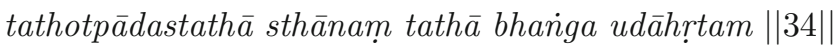

(Madhyamakaśāstra 7:34)

Another Madhyamaka doctrine objected to by the author(s) of the Nyāya Sütra:

vartamānābhāvah, patatah patitapatitavyakālopapatteh (Nyāya Sūtra

2.1.40)

Please compare this to the passage:

gatam na gamyate tāvadagatam naiva gamyate | 
gatāgatavinirmuktam gamyamānam na gamyate $\|1\|$

(Madhyamakaśāstra 2:1)

Thus, the Nyāya Sütra cannot be written earlier than the first texts of Madhyamaka and Yogācāra dated not earlier than the 2nd century A.D.

(ii) The Caraka-saṃhitā, a medical treatise, includes many passages about pramāna, the sources of knowledge, similar to the Nyāya doctrine, e.g. some sources are as follows:

Pratyakșa - Pratyakșa (perception) is the knowledge which is directly received by the self and the sense organs. Self-perceived are pleasure, pain, desire, aversion etc., while sound etc. are percieved by the sense organs.

Anumāna - Anumāna (inference) is the reasoning supported by invariable concomittance such as the knowledge of agni by the power of digestion, that of strength by the power of exercise, auditory organ etc. by the perception of sound etc.

Aitihya - Aitihya (tradition) is the traditional authoritative source of knowledge such as veda etc.

Aupamya - Aupamya (analogy) is the statement of similarity between things such is - analogy of dandaka with danda (staff), that of dhanuhsthmbha with bow and that of the provider of health with the archer [31, p. 363].

The authorship or at least the deep editorship of this treatise is ascribed to Caraka, the great physician who was the medical attendant of Kanișa (the 2nd century A.D.), the Emperor of the Kușānas. So, in the Chinese text of the Samyukta-ratna-pitaka Sütra it is stated that Kanișka had the following three friends: his prime minister Mathara, the physician Caraka, and the poet Aśvaghoșa [15]. As we thus see, Caraka is considered a resident of Gandhāra, the Greco-Buddhist region.

Let us notice that there are many evidences that the Madhyamaka was founded in the same Gandhāra, too. First of all, there is an archeological evidence. The fragments of the Astasāashasika Prajñāpa aramitā, the protoMadhyamaka book, written in the Kharoșthī script in the Gāndhārī language and dated to ca. 75 A.D. by the radiocarbon analysis were reconstructed by Harry Falk and Seishi Karashima [7]. They found out that these fragments are supposed to be a source text for the first Chinese translation of the Aștasāhasrikā Prajñāpāramitā by Lokakșema (ca. 179 A.D.). Also, they proved linguistically that the standard Sanskrit text can be a translation from Gāndhāri, because in Sanskrit there are many expanded phrases that are not present in the Gāndhārī source at all: "the language of the original text was Gāndhāri, just as was assumed on the basis of some expressions in Lokakṣema's translation which presuppose sound changes only found in Gāndhāri, and not in other Indian vernaculars of the time" [7].

Some other fragments of Mahāyāna texts excavated in Gandhāra are: (i) the Gāndhārī manuscripts SC1 (PP-G, similar to the ASP 40), BC2 (Bajaur 
Mahāyāna sūtra with parallels to the Akșobhya vyūha) in Kharoșthī dated to the first or second century A.D.; (ii) the Sucitti-sūtra (NC2, similar to the Vimalakìrtinirdeśa-sūtra) with parallels to three Chinese translations (T477479) and the Pratyutpannabuddhasammukhāvasthitasamādhi-sūtra, both written in Kharoșthī and dated to the 1st or 2nd century A.D.; (iii) several small palm leaf fragments from Bamiyan with text passages familiar from the Bodhisattvapitaka-sūtra, the Sarvapunyasamuccaya samādhi-sūtra, and the Bhadrakalpika-sütra, written in Kharosthị̄ and dated to the 3th/4th century A.D., etc. [28].

We know that the prajñāpa aramitā teaching was very popular in the NorthWest of India in the Kușāna period. In the Mañjuśrīmūlakalpa (LIII v. 575) it is affirmed that under Kaniṣka the prajñāpāramitā was 'established' (pratisthit $\bar{a}$ ) in the North-West. This doctrine with the śūnyatā concept served as a background for the fragments $\mathrm{BC} 4$ and $\mathrm{BC} 11$. In $\mathrm{BC} 4$ we read 'benefit of free-

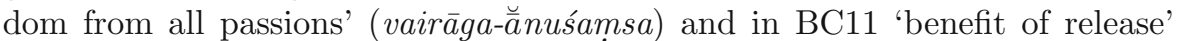

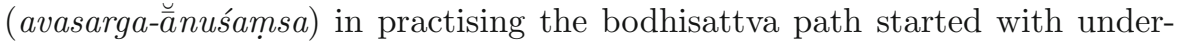
standing ( parijñ $\bar{a}$ ) the origins of suffering and finished at abandoning (prahāna) these origins and realising the emptiness of all dharmas within a direct realization of the unconditioned (lokottara-bhūta-jñanna) [28].

There are some textological evidences that Nāgārjuna was a resident of the Kusāna Empire. It is stated in the Rājataramgiñ $\bar{\imath}$ dating from the 12th century that Nāgārjuna was a lord of the earth (bhūmīśvaro) in Kāśmīr under the rule of the following three Kuṣāna Emperors: Huṣka, Juṣka, Kaniṣka:

athābhavan svanāmankapuratrayavidhāyinah |

huṣkajuṣkakaniṣk ākhyās trayas tatraiva pārthivah ||168||

sa vihārasya nirmātā juṣko juṣkapurasya yah |

jayasvāmipurasyāpi śuddhadhīh samvidhāyakah \|169\|

te turuṣkānvayodbhūtā api punyāśrayā nrpāh |

shuṣkaletrādidesheșu mathacaityādi cakrire ||170||

prājye rājyakșane teșām prāyah kāśmīramaṇdalam |

bhojyam aste sma bauddhānām pravrajyorjitatejasām ||171||

tad̄̄ bhagavatah śākyasimhasya paranirvṛteh |

asmin mahilokadhātau sārdham varșaśatam hy agāt ||172||

bodhisattvaś ca deshe 'sminn eko bhūmīśvaro 'bhavat |

sa ca nāgārjunah srhīmān sadārhadvanasamsrhayi \|173\||

(Rājataramgin̄i 168-173).

Hiouen Thsang, who visited India in 645 A.D., mentions Aśvaghoṣa, Deva, Nāgārjuna, and Kumāralabdha, as the contemporaries of Kanișka and 'as the four suns which illumine the world'. Aśvaghoṣa is named also the spiritual advisor of Kaniṣka [3, pp. 302-303].

Hence, in order to prove that the Nyāya Sūtra was created in Gandhāra in the 2 nd century A.D. (or later) indeed, we should trace the proto-Nyāya teaching (first of all, the pramāna doctrine) in the Buddhist sources before the 
Mahāyāna and show that this teaching can have been established in Gandhāra. This would give a new argument supporting the dating of the Nyāya Sütra to the 2nd century A.D.

\section{Discussion on Methodology}

According to some recent results in experimental psychology and cognitive science, systematic (or symbolic) logic is not an 'innate' knowledge of human beings. In order to know logic, we should especially study it and, first of all, study the ways how it can be applied in different situations: public discourse, science or private strategy. As a consequence, we can use strategic, creative or even critical thinking without any logical competence if we did not study systematic logic before, and even if we have studied it, we usually do not follow it in life. At first, psychologists Amos Tversky and Daniel Kahneman showed that even experts take current decisions without using systematic logic. Therefore, they established a research programme in cognitive science to study cognitive heuristics and biases, i.e. ways of making decisions in life: decisions in risk situations, prompt decisions, creative decisions and so on [41].

In the paper, I try to find out the origin of the emergence of logic in India according to the Pāli texts.

Logic is based on distinguishing particulars and generals. Let us consider an example from the Pāli Canon-how particulars and generals are examined in the Yamaka. In Sanskrit yamaka means 'twin' or 'pair' and it is used to denote a rhetoric trope with a repetition of words after their permutation. In the Nātyaśāstra (dated to between 200 B.C. and 200 A.D.) there are enumerated excellent points (laksana) of a good dramatic composition (kāvya) and yamaka belongs to one of the four "rhetorical figures of speech" (alamkāra), used when composing dramas. These four figures are as follows: simile (upam $\bar{a})$, metaphor (rūpaka), condensed expression (dīpaka), and yamaka.

In the Pāli treatise Yamaka the repetition of two words $A$ and $B$ after their permutation is used to show what a general is from $A$ and $B$ and what a particular is. So, this book considers many different pairs of dhammas $A$ and $B$ by questions: 'Is $A B$ ? But is $B A$ ?' Answering both questions allows us to define an inclusion relation respectively: 'Is $A$ a subset of $B$ ' or 'Is $B$ a subset of $A$ ?' There are possibly four answers: (i) $A$ is a subset of $B$ and $B$ is a subset of $A(A=B$, i.e. $A$ and $B$ are of the same generality); (ii) $A$ is a subset of $B$ and $B$ is not a subset of $A(A \subset B$, i.e. $A$ is particular and $B$ is general); (iii) $A$ is not a subset of $B$ and $B$ is a subset of $A(B \subset A$, i.e. $A$ is general and $B$ is particular); (iv) $A$ is not a subset of $B$ and $B$ is not a subset of $A$ ( $A$ and $B$ are not comparable).

These four possible answers to the question 'Is $A \quad B$ ? But is $B A$ ?' can be represented as the following four converses of the universal affirmative syllogistic proposition 'All $A$ are $B$ ': (i) 'All $A$ are $B$ ' and 'All $B$ are $A$ '; (ii) 'All $A$ are $B$ ' and 'Not all $B$ are $A$ ' (i.e. 'Some $B$ are not $A$ '); (iii) 'Not all $A$ are $B$ ' (i.e. 'Some $A$ are not $B$ ') and 'All $B$ are $A$ '; (iv) 'Not all $A$ are $B$ ' (i.e. 'Some $A$ are not $B$ ') and 'Not all $B$ are $A$ ' (i.e. 'Some $B$ are not $A$ '). 
For instance:

(Ka) ye keci kusalā dhammāa, sabbe te kusalamūla $\vec{a}$ ?

(Kha) ye vā pana kusalamūlā, sabbe te dhammā kusalä?

(Yamakapāli, 1 Mūlayamakam 1.1)

All faultless states (are present). Are they all faultless roots?

These faultless roots (are present). Are they all faultless states? [19, p. 22].

Thus, among all the converses from (i) to (iv) for all pairs considered in the Yamaka we see just a correct declaration of what a general is and what a particular is and, at the same time, we cannot find out logical inference rule, even in respect to converse or inverse. For example, we know that from 'All $A$ are $B$ ' it follows logically that 'Some $B$ are $A$ ' (conversation). Nevertheless, the author(s) of the Yamaka does not know this rule, see also [11, pp. 306-310]; [44, pp. 152] as well as others. This fact is apologetically explained as follows:

The Yamaka does not consist of a set of logical exercises and is not a textbook on applied logic at all. The members of the pairs of statements do not stand to each other in the logical relation of one being an immediate inference of the other. To conceive them as such is wholly to misunderstand the purpose of the book, which is not an exercise in logical gymnastics, but is intended to convey to the reader the exact logical boundaries of important concepts in the light of their actual technical usage [11, p. 309].

So, on the one hand, the Yamaka demonstrates a well-developed philosophical discourse with distinguishing particulars and generals. But, on the other hand, its author does not express any knowledge of logical rules for inferring.

This situation with the Yamaka is an example of adopting the first method applied in this paper, called a structural analysis of logical competence. We can always detect this competence or its deficit by textual analysis: whether there are some evidences of inference rules which are correct from the standpoint of symbolic logic. Even if the author demonstrates a philosophical discourse with some logical notions, but (s)he also often uses sophisms or does not apply inference rules at all, this means that (s)he does not have true logical competence.

Logic is a part of algebra and logical competence means that the author can combine some lexemes algebraically, e.g. (s)he can draw true conclusions from true premises mechanically by means of some algebraic tools.

In fragments of trial records and omens written in Akkadian we can detect some algebraic tools used for trial decisions and forecasting. Hence, the authors of these fragments possessed good logical competence. In India, for example, this good competence is detected in the texts written by representatives of the Hindu schools of Nyāya and Vaiśeșika and by representatives of the Buddhist schools of Madhyamaka and Yogācāra.

The Kalahavivāda-sutta (Sutta-nipāta 4.11) is another example from the Pāli Canon in which the author involves difficult logical notions without any logical inference rules. In this discourse, for rhetorical purpose the author uses 
a transitivity of implications, when several implications with a joint part can be combined among themselves to build sorities [44, pp. 130-136]. Nevertheless, the author implements semantically true transitions some of which are not correct formally.

The Pāli Canon is a unique Indian text corpus, because we have a chance to observe how the logical competence of its authors continuously grew up from zero in analyzing the same subject of abhidhamma. The first definitions of dhammas and the first logical divisions of their concepts contained many fallacies because of 'mutually intercrossing, over-lapping or partially coinciding notions,' see an appropriate apologetics for this fact in [11, p. 294]. But later they became correct and there were two ways of division: (i) by choosing contradictory terms (e.g. in classifying some dukas (pairs) (see [44, p. 49]); (ii) and by choosing contrary terms with a neutral between them (e.g. in classifying some tikas (triplets): sukha (happiness), dukkha (unhappiness), and adukkhamasukha (neither unhappiness nor happiness) (see [44, p. 52]).

In reconstructing the history of logical competence of the authors of the Pāli Canon I appeal to the second method, historical reconstructive hermeneutics. This hermeneutics allows us to examine texts diachronically and it is grounded on the motto of Ludwig Wittgenstein: 'use as meaning' according to which we should reconstruct meanings of words on the basis of understanding their contextual use.

This hermeneutics is the opposite of the philosophical synchronic hermeneutics. The latter examines texts synchronically for the sake of philosophical inspirations. It can be productive from the point of view of philosophy, although it is not scientific. For instance, sometimes the Abhidhamma is analyzed by Ronkin [26] by the philosophical synchronic hermeneutics, e.g. when she compares abhidhamma and the vaiśesika way of classifying categories. On the one hand, this comparison is interesting philosophically, but, on the other hand, it ignores the fact that the Vaiśeșika classification of categories demonstrates a good logical competence, while the Pāli classifications were proposed at a different time and some of them are not perfect logically. So, from the standpoint of historical reconstructive hermeneutics the latter fact would mean that some Pāli classifications of dhammas were created earlier than the Vaiśeșika classification. Historically, the Vaiśeșika one can be compared to the Abhidharmakośakārikā of Vasubandhu, because their logical competences are comparable and perfect simultaneously.

Some versions of philosophical synchronic hermeneutics can be even absurd historically. For instance, according to the Mīmāmsā hermeneutics the Nyāya school of logic existed at the time of Krṣna and Arjuna, as the word of nyāya is mentioned in the Mahābhārata:

The sciences called $\boldsymbol{n y} \boldsymbol{y} \boldsymbol{y} \boldsymbol{a}$, orthoephy and treatment of diseases; $\langle\ldots\rangle$ a description of places of pilgrimage and other holy places of rivers, mountains, forests, the ocean, of heavenly cities and the kalpas; the art of war $<\ldots>$ (Mahābhārata 1.1.52).

The historical reconstructive hermeneutics allows us to trace back the logical competence of the authors of the Pāli Canon. In $[11,44]$ there is proposed 
a well-grounded reconstruction of logical discourse in the early Pāli texts, although the first book is quite subjective, because its author tries to be so apologetic for Theravāda. In both books their authors note that from the very beginning, the abhidhamma as well as other texts was often taught in the form of questions and answers and, as a result, some (proto-)logical techniques were thought up for the purpose of rhetoric.

For example, in the Nikāyas and Āgamas the following four kinds of explanations of questions were proposed [11, p. 281]; [44, pp. 72-73]: (i) ekamsavyākaran̄yyo, a categorical explanation when a questioner demands 'Yes' or 'No' from an answerer; (ii) patipucchā-vyākaran̄ỹyo, an answer by a counterquestion when an answerer returns a reply in the form of a new question; (iii) thapaniyo, when a questioner suggests some reply to an answerer but all such suggestions are set aside as inapplicable; (4) vibhajja-vyākarañỹo, an analytical explanation when a questioner requests some explanation of an answerer.

One of the first logical tools represented in the Pāli texts is to classify things according to the following four-fold assertions: (i) $S$ is $P$; (ii) $S$ is not $P$; (iii) $S$ is and is not $P$; (iv) $S$ neither is nor is not $P$. For instance, the Buddha engages these four-fold assertions to show that none of them 'fit the case' (upeti). Thus he says that when an enlightened person dies: (i) 'he is reborn ... does not fit the case' (upapajjati ti ... na upeti); (ii) 'he is not reborn ... does not fit the case' (na upapajjati ti ... na upeti); (iii) 'he is and is not reborn ... does not fit the case' (upapajjati ca na ca upapajjati ti ... na upeti), (iv) 'he is neither reborn nor not reborn ... does not fit the case' (n'eva upapajjati na na upapajjatī ti ... upeti) (Majjhima Nikāya 1.486; [11, p. 289]). This type of answer corresponds to the following strategy in questioning: (i) 'Is $S P$ ?'; (ii) 'If not, is $S$ not $P$ ?' (iii) 'If not, is $S$ both $P$ and not $P$ ?' (iv) 'If not, is $S$ neither $P$ nor not $P$ ?'

As we see, the first logical techniques, such as the four-fold assertions, which were invented in the Pāli Canon, were used, first of all, for some rhetorical purposes.

Thus, in this paper I propose the structuralist analysis of logical competence, how it is expressed in the Pāli Canon, by means of the historical reconstructive hermeneutics. My aim is to show that the Milindapañha is a unique Pāli text close to the true original point of logic's emergence in India.

\section{Some Occurrences of the Terms 'Logic', 'Logical' in the Pāli Canon}

The Milindapañha consists of many short dialogues and each dialogue can be examined as (or reduced to) a syllogism with the following four steps:

(a) Is $A \quad B$ ? (question or thesis);

(b) $A$ is (not) $B$, because... (argumentation or inference, anumāna);

(c) The illustration for inference (b) is as follows: ... (example, opamma);

(d) Accepting or denying (a) on the basis of (b). 
This structure of syllogism proposed in the Milindapañha holds even for definitions:

(a) "Venerable Nāgasena, what is the differentia (distinguishing characteristic) of $A$ ?"

"Bhante nāgasena kimlakkhan̄a A?" Ti.

(b) "The differentia of $A$, your majesty, is $B . "$

"B -lakkhañ̄ mahārāja $A$ " ti.

(c) "Give me an illustration."

"Opammam karoh $\vec{\imath}$ ti.

Then the Nāgasena illustration follows.

(d) Accepting the definition put forward by Nāgasena.

"Kallo'si bhante nāgasen $\vec{a} "$ ti.

Let us notice that this kind of definition is very close to the Aristotelian model of genus-differentia definitions: the item is defined through its differentia, but the difference from Aristotle is that Nāgasena always verifies his definitions by examples.

In the Milindapañha there is no name for the four-step syllogisms. The word $\tilde{n} \bar{a} y a$, the Pāli analogue for the Sanskrit nyāya, occurs in the meaning 'the method, the dhamma' ñāya dhamma (Milindapañha 6.1.3), i.e. as a method, distinguishing Buddhists from non-Buddhists. Let us emphasize that $\tilde{n} \bar{a} y a$ occurs very often in the Pâli Canon, but never in the meaning of the Hindu school of logic. In most cases it means an analytic method or even a Buddhist method of cognition distinguishing Buddhists from non-Buddhists. For example, there is an expression 'the noble method' (ariya cassa ñaya) in the Gahapativagga of the Samyutta Nikāya:

At Savatthī. Then the householder Anathapiṇdika approached the Blessed One, paid homage to him, and sat down to one side. The Blessed One then said to him:

"Householder, when five fearful animosities have subsided in a noble disciple, and he possesses the four factors of stream-entry, and he has clearly seen and thoroughly penetrated with wisdom the noble method, if he wishes he could by himself declare of himself: 'I am one finished with hell, finished with the animal realm, finished with the domain of ghosts, finished with the plane of misery, the bad destinations, the nether world. I am a stream-enterer, no longer bound to the nether world, fixed in destiny, with enlightenment as my destination" [5, vol. 1, p. 578].

Sāvatthiyam viharati. Atha kho anāthapindiko gahapati yena bha-

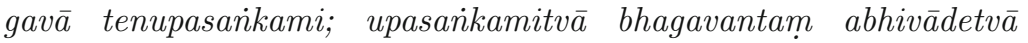
ekamantam nisīdi. Ekamantam nisinnam kho anāthapiṇdikam gahapatim bhagavā etadavoca: 
"Yato kho, gahapati, ariyasāvakassa pañca bhayāni verāni vūpasantāni honti, catūhi ca sotāpattiyangehi samannāgato hoti, ariyo cassa ñāyo paññaya suditțo hoti suppatividdho, so ākaìkhamāno attanāva attānam byākareyya: 'khīnanirayomhi khīnatiracchānayoni khīnapettivisayo khīnāpāyaduggativinipāto, sotāpannohamasmi avinipātadhammo niyato sambodhiparāyano'ti" (Samyuttanikāya, Pañcaverabhayasutta $41-42$ [Gahapativagga]).

Also, there is an expression 'the method, the dhamma' (ñaya dhamma) in other texts:

At Savatthī. "Bhikkhus, whether for a layperson or one gone forth, I do not praise the wrong way. Whether it is a layperson or one gone forth who is practising wrongly, because of undertaking the wrong way of practice he does not attain the method, the Dhamma that is wholesome [5, vol. 2, p. 1536].

Sāvatthinidānam. "Gihino vāham, bhikkhave, pabbajitassa vā micchāpatipadam na vannememi. Gihi vāa, bhikkhave, pabbajito vā micchāpațipanno

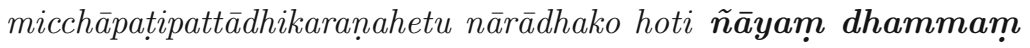
kusalaṃ (Saṃyuttanikāya, Mahāvaggapāli 1.24 [Dutiyapațipadāsutta]).

Contextually, only the Milindapañha among other Pāli texts assumes that ñāya should include 'logic' - by assuming the four-step syllogism as a tool of true cognitions. As we see, the Milindapañha is unique not only because of its historical context (the only Pāli book directly connected to Gandhāra), but also due to its respect for syllogisms as a part of the method of Buddhists. The point is that the doctrinal difference between the Theravāda and the Mahāyāna teaching is significant, indeed, but the most intriguing difference holds in respect to logic. While in the Mahāyāna there are many logical treatises and logic is regarded as one of the most important Buddhist sciences and arts, in the Theravāda there is no interest in logic as such, there are no logical treatises in the strict sense. That fact is in line with the Buddha's words concerning logical matters in the earliest sūtras (Pāli: suttas). Let us refer to the Kālàma Sutta contained in the Ariguttara Nikāya of the Tipitaka, the Pāli Canon. In this sutta, the Buddha sounds a note of caution on the subject of what should be avoided in Buddhism:

Come, Kālāmas. Do not go upon what has been acquired by repeated hearing; nor upon tradition; nor upon rumour; nor upon what is in a scripture; nor upon surmise; nor upon an axiom; nor upon specious reasoning; nor upon a bias towards a notion that has been pondered over; nor upon another's seeming ability; nor upon the consideration, 'The monk is our teacher.' Kālāmas, when you yourselves know: 'These things are good; these things are not blameable; these things are praised by the wise; undertaken and observed, these things lead to benefit and happiness,' enter on and abide in them $[40$, p. 5]. 


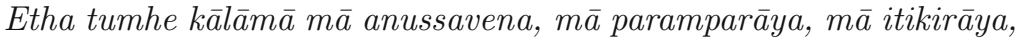

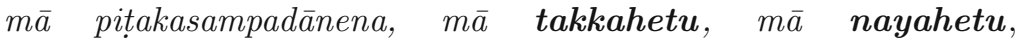

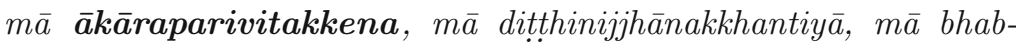

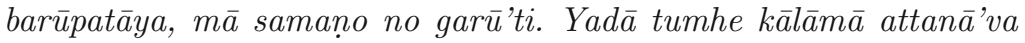

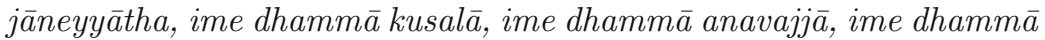

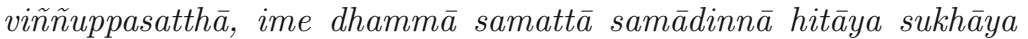
samvattant̄̄'ti. Atha tumhe kālāmā upasampajja vihareyyātha (Tikanipātapāli 66 [Kālāmasutta I.189]).

In this short quoted text, the Buddha talks about things which are similar to idols of the mind (idola mentis) proposed by Francis Bacon (1561-1626). For example, the Buddha warns us against traditional visions and dogmas including 'repeated hearing' (anussava), 'tradition' (paramparā), 'rumor' (itikir $\bar{a})$, 'following a scripture' (pitaka-sampadāna), 'following an authority' (bhabbarūpatāya and samano no gar $\bar{u}$ ). Meanwhile, he warns us against any logical reasoning, too. Namely, first, he talks against 'surmise' (takkahetu), which is better to be translated as 'because of (deductive) reasoning'. It means that any truth of dhamma (the Buddha's teaching) cannot be proven by inferring from premises. Second, the Buddha warns us against 'an axiom' (nayahetu), making an assumption to be verified later. Third, he avoids 'specious reasoning' (ākāraparivitakka), accepting something after considering its reasons. Fourth, he criticizes 'a bias towards a notion that has been pondered over' (ditthinijjhānakkhantiyā), starting from some view or opinion (ditthi).

Hence, according to the Kālāma Sutta, logical matters (e.g. the art of debates) are excessive for Buddhism and logical reasoning is not enough for our liberation. Another commentary to this sutta is by Watanabe [44, p. 105]. We should just analyze our own action (kamma) and its consequences or effects (phala). The same attitude towards logical subjects is seen in the Theravāda (i.e. relatively early) Buddhism, as well.

In many other early suttas, such as some in the Sutta-nipāta, the Buddha expresses the same sceptical view of logical reasoning, e.g.:

\section{Buddha:}

Indeed, there are not many and varied truths

differing from perception of the ever-true in the world;

but they work upon their views with logic:

"Truth! Falsehood!" So they speak in dualities.

Based on what is seen, heard,

On precepts and vows, or what is cognized,

They look down on others.

Convinced of their own theories,

pleased with themselves,

They say, "My opponent is a fool, no expert."

[16, p. 279]. 
Na heva saccāni bahūni nānā,

Añ̃atra sañ̃̃āya niccāni loke;

Takkañca dițthīsu pakappayitvā,

Saccam musāti dvayadhammamāhu.

Ditthe sute sīlavate mute vā,

Ete ca nissāya vimānadassī;

Vinicchaye thatvā pahassamāno,

Bālo paro akkusaloti cāha."

(Suttanipātapāli 892-893 [Cūlabyūhasutta]).

Thus, the word ñāya, the Pāli analogue for the Sanskrit nyāya, never occurs in the Pāli Canon in the meaning of the school of logic or the Nyāya Sütra. The only case that seems to be a mention of the school of logic is as follows. In the Milindapañha, Menander or Milinda was regarded as an excellent expert in all the 19 Hindu sciences and arts:

Of these two the novice became the King called Milinda in the city of Sagala in India. He was wise, experienced, clever, able; he was one who acted conscientiously at the time of doing all the (magic) devices, ceremonies and observances concerning things past, future and present. Many were the arts he had mastered, that is to say: the revealed tradition, secular lore, the Sankhya, Yoga, Nyāya, and Vaiśeśika systems, accountancy, music, medicine, the four Vedas, the Purāṇas, the oral traditions, astronomy, conjuring, logic, spells, fighting, poetry, reckoning on the fingers, in a word, the nineteen (arts) $[10$, vol. 1, p. 5].

So, the Greek king was represented as a scholar even in the Hindu philosophy, including the doctrines of the Sāmkhya, Yoga, Nyāya, and Vaiśeșika Schools. The problem is that T. W. Rhys Davids and then I. B. Horner have translated this fragment not correctly. Let us quote the same text in Pāli:

Tesu sāmaṇero jambudīpe sāgalanagare milindo nāma rājā ahosi. Pandito byatto medhāvi pațibalo atītānāgatapaccuppannānam mantayogavidhānakiriyānam, karaṇakāle nisammakārī hoti, bahūni cassa satthāni uggahitāni honti. Seyyathidam-suti sammuti saìkhyā

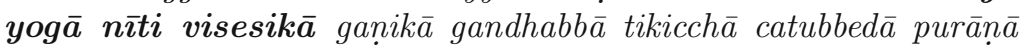

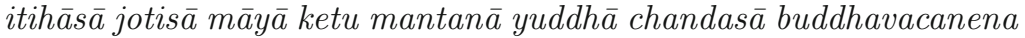
ekūnavīsati, vitanḍavād̄̄ durāsado duppasaho puthutitthakarānam aggamakkhāyati, sakalajambud̄̄pe milindena raññā samo koci nāhosi yadidam thāmena javena sūrena paññ̄ya, aḍ̣̂o mahaddhano mahābhogo anantabalavāhano (Milindapañha 1.1.4).

We are reading here just sankhyā yogā nīti visesikā, i.e. the Sāmkhya, Yoga, Niti, and Vaiśeșika Schools, not Nyāya. The fact that the word nyāya in the meaning of the Hindu doctrine or school of logic does not occur in the Pâli Canon at all is significant evidence for us that Nyāya did not exist before the 1st century A.D., at time when approximately, but not earlier the Pāli 
Canon was finally edited. The translation of $n \bar{\imath} t i$ as nyāya is a kind of historical falsification. First of all, nyāya is a teaching concerning pramāna how to verify or falsify logical reasoning. And, as we try to prove, this teaching did not exist before the 1st century A.D.

Let us examine the 19 Hindu sciences and arts for which Menander was said to be a great scholar: (1) suti veda - the Hindu holy texts presented by the Vedas; (2) sammuti - moral codes and sage advices such as the Manusmrti or Manu's Code of Law finally edited after 400 A.D.; (3) sarikhyā - the Sāṃkya

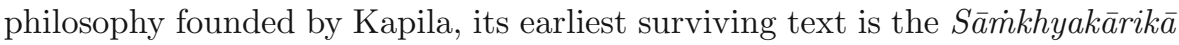
written by Iśvarakṛṣna from the 3rd to the 4th century A.D.; (4) yog $\bar{a}-$ the yoga philosophy founded by Patañjali, its basic text is the Yoga Sütra dated from the 2 nd to the 4th century A.D.; (5) nitti-the nitti philosophy or political philosophy including several arts: diplomacy and statecraft (Pāli: rajanīti); economics (Pāli: atthanīti); morality (Pāli: lokanīti); ethics (Pāli: dhammaniti); the Buddhist ethics that included didactic stories and maxims on numerous everyday subjects (Pāli: vaddhananīti); (6) visesik $\bar{a}$ - the Vaiśeșika philosophy founded by Kaṇāda, its basic text is the Vaiśeșika Sūtra cited, e.g., the Jñānaprasthāna-śāstra, one of the seven books of the Sarvāstivāda Abhidharma written from the 1st to the 2nd century A.D.; thus, the abhidharma (Pāli: abhidhamma) is a Buddhist alternative to vaiśeșika; (7) ganik $\bar{a}$ arithmetics; (8) gandhabb $\bar{a}$ - the Hindu literature on music; (9) tikicch $\bar{a}$ - the Hindu medicine; (10) catubbed $\bar{a}$ - the art of archery; (11) purān $\bar{a}$ - the corpus of histories and ancient tales; (12) itih $\bar{a} s \bar{a}$ - the Hindu chronics saying 'it happened thus', such as the Mahābhārata; (13) jotis $\bar{a}$ - the Hindu astrology that was influenced by the Greek astrology in the higher measure, because the Yavanajātaka (or the Greek Jātaka), a book on astrology translated from Greek in the 2nd century A.D., was one of the earliest sources of the Hindu astrology [22]; (14) māy $\bar{a}$ - the knowledge of stratagem; (15) ketu that is traditionally read by the Theravāda as hetu - the art of weighing and analyzing the pro et con of the matter in question, in the way it was demonstrated in the Kathāvatthu; however, if it is ketu indeed, then it means Hindu omens; (16) mantan $\bar{a}$ - the Hindu art of incantations and sacrificial formulas; (17) $y u d d h \bar{a}$ - the art of warfare; (18) chandas $\bar{a}$ - the Hindu art of reciting and composing hymns and poetry; (19) buddhavacanena - all the words of the Buddha, including the Pāli Canon.

For the first time, $\tilde{n} \bar{a} y a$ was used with the same kind of meaning of the Hindu school of logic, most probably, of Buddhist logic, just in the Dathavansa or the History of the Tooth-Relic Gotama Buddha written not earlier than in the 5th century A.D.:

Then priests, wise and skilled in the Tipițaka, Jātaka, Logic [A.Sch.- ñāya], Agāma, and the like, and citizens who had their sole refuge in the three treasures, assembled there instantly through curiosity [37, p. 72].

However, the meaning 'the method of Buddhists' was preserved also: 
Who, again, as the hog Tundila, satisfied the people with the taste of the nectar of the Law, and as a sage, composing a treatise on logic $[A . S c h .-\tilde{n} \bar{a} y a]$, made his own Law prevail for a long time [37, p. 51].

For the meaning of 'logical inference' there is another Pāli analogue of nyāya, presented by naya. In this meaning the term of naya occurs often together with the term hetu in the same way as in the Kālama Sutta quoted above, for example in the Jātaka:

Narada replied:

"Ask me, O king; this is thy business; this doubt of thine which thou feelest, I will assuredly solve it for thee by reasoning, by logic, and by proofs."

"Pucchassu mam rāja tavesa attho, Yam samsayam kuruse bhūmipāla; Aham tam nissamsayatam gamemi, Nayehi $\tilde{n} \bar{a} \boldsymbol{y e h i}$ ca hetubhī ca" (Jātaka, 544, Mahānipāto 1298 [Mahānāradakassapajātaka]).

The next instance of the same occurrence is taken from the Mahãvagga of the Ariguttara Nikāya, where the Buddha also expresses a kind of scepticism about any logical reasoning:

Come, Salha, do not be satisfied with hearsay or with tradition or with legendary lore or with what has come down in scriptures or with conjecture or with logical inference or with weighing evidence or with a liking for a view after pondering it or with someone else's ability or with the thought 'The monk is our teacher' [39].

Etha tumhe, sālh $\bar{a}, m \bar{a}$ anussavena, mā paramparāya, mā itikirāya, mā pitakasampadānena, mā takkahetu, mā nayahetu, mā ākāraparivit-

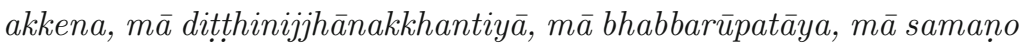
no garūti (Ariguttaranikāya I.193, Tikanipātapāli 66 [Sālhasutta]).

Thus, the term nyāya in the meaning of the Hindu school of logic or the Nyāya Sütra does not occur in the Pāli Canon, actually. Instead of that the Pāli term $\tilde{n} \bar{a} y a$ had the meaning of one or other aspect of the wisest Buddhist method and, according to the Milindapañha, the four-step syllogisms are an important part of cognitions within this method.

\section{Logical Reconstructions of Some Conclusions in the Kathāvatthu}

The Milindapañha is organized as a compendium of four-step syllogisms explaining abhidhamma. There is else only one similar treatise, pakarana, written especially for the purpose of debates with non-Theravādins (more precisely historically, with non-Vibhajjavādins) for teaching the abhidhamma. This compendium of logical reasoning for different debates is called the Kathāvatthu, it is contained in the Abhidhamma Pitaka of the Pāli Canon. In this Section I will try to show that its author(s) had no competence in logic because of many fallacies, although a lot of syllogisms of the Kathavvatthu are correct and really difficult. This is the main difference of that book from the Milindapañha, where 
there are no logical fallacies at all. For another logical reconstruction of the Kathāvatthu, please see [11, pp. 305-368] and [44, pp. 122-126; pp. 154-174].

In this treatise we find many correct complex syllogisms, such as modus tollens: 'If $A$ is $B$, then $C$ is $D$. But $C$ is not $D$. Therefore, $A$ is not $B$ ' [1, p. xlviii]:

Adherent.-Is $A B$ ? (thapan $\bar{a})^{4}$

Opponent.-Yes.

Adh.-Is $C D ?($ papana $\bar{a})$

Opp.-No.

Adh.-But if $A$ be $B$, then [you should have said] $C$ is $D$. That $B$ can be affirmed of $A$, but not $D$ of $C$, is false. Hence your first answer is refuted. $(\operatorname{ropan} \bar{a})$.

Formally:

$$
\begin{aligned}
& (A \Rightarrow B) \Rightarrow(C \Rightarrow D) ; \neg(C \Rightarrow D) \\
& \neg(A \Rightarrow B) .
\end{aligned}
$$

Another example of correct syllogism as a modification of modus tollens is logically formulated in the Kathāvatthu as follows: 'If $D$ be denied of $C$, then $B$ should have been denied of $A$. But you affirmed $B$ of $A$. Therefore, that $B$ can be affirmed of $A$, but not $D$ of $C$, is wrong,' or in the simpler way: 'If $C$ is not $D$, then $A$ is not $B$. But $A$ is $B$. Therefore $C$ is $D^{\prime}$ [1, p. xlviii]. Formally:

$$
\neg(C \Rightarrow D) \Rightarrow \neg(A \Rightarrow B) ;(A \Rightarrow B)
$$

$$
(C \Rightarrow D) \text {. }
$$

One of the most interesting items of evidence for the genuine role that logic plays in Theravāda Buddhism is contained in the first chapter of this text, called the Puggalakath $\bar{a}$; the latter describes a debate between a Theravādin (more precisely historically, Vibhajjavādins), who is considered an orthodox Buddhist in the text, and a Puggalavādin, another Buddhist who believes in the existence of a soul-like personal entity (puggalo). The point is that the reasoning involved in the debate from the opposite sides shows that the Theravādin as well as the Puggalavādin do not understand the subject of logic as ultimate inferring, although they use correct syllogisms sometimes.

Let us introduce some symbolic notations to make their debate more transparent:

$A$ is $B:=$ "The person" (puggalo) is known in the sense of a real and ultimate fact.'

\footnotetext{
${ }^{4}$ Let us notice that in symbolic logic the proposition " $A$ is $B$ " always has the formal meaning of implication: "if $A$, then $B$ " $(A \Rightarrow B)$ or "if something is $A$, then it is $B$, too" $(A \Rightarrow B)$. This formal treatment of affirmative propositions in the way of implications was well known by Indian logicians such as Dharmakīrti (he was a representative of Yogācāra school). He exemplifies this relationship as follows: "Dalbergia is a tree". As a consequence, it means that if something is a Dalbergia, then we can conclude that it is a tree, too, but not vice versa.
} 


\section{Puggalo upalabbhati saccikațthaparamatthenāti (Kathāvatthu 1).}

$A$ is $C:=$ "Is "the person" known in the same way as a real and ultimate fact is known?'

Yo saccikattho paramattho, tato so puggalo upalabbhati saccikatthaparamatthenāti? (Kathāvatthu 1).

Then their debate is taking place in the following manner:

Theravādin.-Is $A B$ ?

Puggalavādin. - Yes.

Ther.-Is $A C$ ?

Pugg.- -No.

Ther.-However, 'if $A$ is $B$, then $A$ is $C$.' Then that which you say here is wrong, because you state that ' $A$ is $B$ ' is true, but ' $A$ is $C$ ' is false. But if ' $A$ is $C$ ' is false, then ' $A$ is $B$ ' is false.

Symbolically:

$$
\begin{aligned}
& (A \Rightarrow B) \Rightarrow(A \Rightarrow C) ; \neg(A \Rightarrow C) \\
& \neg(A \Rightarrow B) .
\end{aligned}
$$

It is an ad absurdum, because $A \Rightarrow B$ is held by the Puggalavādin to be true. The Theravādin holds that this should mean that that $A \Rightarrow C$ is true, too. Hence, we see that the final refutation is logically correct, according to the Theravādin understanding of the terms $A$ and $B$, here: 'If $A$ is $B$, then $A$ is $C$.' So, if ' $A$ is $B$ ' is true, ' $A$ is $C$ ' should be true, too. The Puggalavādin maintains that ' $A$ is $C$ ' is false. However, it means, as the Theravādin truly claims, according to their analysis that ' $A$ is $B$ ' should be false, also. This syllogism is a classical modus tollens. Hence, the Theravādin has just refuted the Puggalavādin's opinion. But, let us look at the continuation of this dialogue:

Puggalavādin.-Is $A$ not $B$ ?

Theravādin.-Yes, it is not.

Pugg.- Is $A$ not $C$ ?

Ther.-No, it is.

Pugg.-However, 'if $A$ is not $B$, then $A$ is not $C$.' Then that which you say here is wrong, namely, that ' $A$ is not $B$ ' is true, but ' $A$ is not $C$ ' is false. But if ' $A$ is not $C$ ' is false, then ' $A$ is not $B$ ' is false, also. Thus, you are wrong.

Pugg.- So, if ' $A$ is not $B$ ' is true, then ' $A$ is not $C$ ' is true. Now we, who admitted these propositions, do not consider ourselves to have been refuted. You say you have refuted us; anyway we are not well refuted.

Symbolically:

$$
\neg(A \Rightarrow B) \Rightarrow \neg(A \Rightarrow C) ; \neg \neg(A \Rightarrow C)
$$




$$
\neg \neg(A \Rightarrow B) .
$$

It is an ad absurdum, as well, because $A \Rightarrow C$ is true for the Puggalavādin. From this it follows that $A \Rightarrow B$ is true, also. So, the Puggalavādin puts forward another implication, namely: 'if $A$ is not $B$, then $A$ is not $C$ ' $[\neg(A \Rightarrow$ $B) \Rightarrow \neg(A \Rightarrow C)]$. The Theravādin states that ' $A$ is not $C$ ' is false. From this it should follow according to the same modus tollens, as the Puggalavādin notes now, that ' $A$ is not $B$ ' is false. It means that the Puggalavādin has just refuted the Theravādin's opinion.

Thus, we have the following opposite sides:

$\begin{array}{ll}\text { Theravādin: } & \text { ' } A \text { is } B \text { ' is false, ' } A \text { is not } B \text { ' is true; } \\ & \text { ' } A \text { is } C \text { ' is true, ' } A \text { is not } C \text { ' is false; } \\ \text { if ' } A \text { is } B \text { ', then ' } A \text { is } C \text { ' } \\ \text { Puggalavādin: } & \text { ' } A \text { is } B \text { ' is true, ' } A \text { is not } B \text { ' is false; } \\ & \text { ' } A \text { is } C \text { ' is false, ' } A \text { is not } C \text { ' is true; } \\ & \text { if ' } A \text { is not } B \text { ', then ' } A \text { is not } C . \text { ' }\end{array}$

In order to apply the same modus tollens, the Theravādin appeals to the implication 'if $A$ is $B$, then $A$ is $C$ ' as the first premise of his syllogism and the Puggalavādin to the same implication, but with negations 'if $A$ is not $B$, then $A$ is not $C$ ' as the first premise of his syllogism. Who is right? Nobody! The problem is that the Theravādin as well as the Puggalavādin cannot agree on the first premise of their reasoning. Their dialogue looks like a logical paradox: the same propositions are true and false at the same time. One opposite side puts forward one implication to prove a contradictory statement. Another side puts forward the same implication, but with negations to prove another statement. Such a dialogue can become interminable. Indeed, we face many modifications of the first dialogue in the Puggalakath $\bar{a}$.

Formally:

Theravādin: $\quad$ if ' $A$ is $B$ ' is true by the Puggalavādin, then ' $A$ is $C$ ' should be true by the Puggalavādin also, but it is not.

Puggalavādin: $\quad$ if ' $A$ is not $B$ ' is true by the Theravādin, then ' $A$ is not $C$ ' should be true by the Theravādin also, but it is not.

The problem is that the author of the Kathāvatthu does not know how the implication $A \Rightarrow B$ can be verified. In the Nyāya and Yogācāra logic, there are the following three ways of verifying the implication: (i) the (Aristotelian) way by showing that $B$ is a general (genus) for $A$; (ii) the (Stoic or Chryssipus) way by checking that $A$ is a cause for $B$; (iii) the (Stoic or Chryssipus) way by checking that $B$ is a sign for $A$ if $A$ is a cause for $B$. Hence, the sentence $A \Rightarrow B$ means, according to Nyāya and Yogācāra, that $A$ implies $B$ as a genus for $A$ or a causal consequence from $A$. There is the third possibility as well that there can be the sentence $B \Rightarrow A$ telling us that the sign $B$ exists for occurring its cause $A$. This semantics for conditional sentences is unknown for the author of the Kathāvatthu. But without a verified implication, modus tollens plays just a rhetorical role.

Thus, on the one hand, the Theravādin as well as the Puggalavādin apply the formally correct modifications of modus tollens mentioned above, but, on 
the other hand, they do not give true inferences, but sophisms in fact, because the Theravādin uses the implication 'if $A$ is $B$ is true, then $A$ is $C$ is true' where the antecedent occurs he considers false and the Puggalavādin uses the implication 'if $A$ is not $B$ is true, then $A$ is not $C$ is true' where there is the antecedent he examines as false, too. However, we cannot infer from the false premises! This significant fact that modus tollens is a sophism because of the unverified implications is ignored by Jayatilleke [11] and Watanabe [44]. A complicated reasoning with many formulas does not mean immediately that its author is a logician. The matter is that this reasoning should be correct formally with, necessarily, correct verifications of all premises.

Let us introduce the following new notations:

$A$ is $B:=$ "The person" (puggalo) is known in the sense of a real and ultimate fact.'

$C$ is $B:=$ 'Material quality ${ }^{5}$ is known in the sense of a real and ultimate fact.'

Then we have the following next dialogue:

Theravādin.- Is $A B$, and is $C B$ ?

Puggalavādin.-Yes.

Ther.-Is $C$ one thing and $A$ another?

Pugg.- No, that cannot truly be said.

Ther.-However, if ' $A$ is $B$, and $C$ is $B$ ', then ' $A$ and $C$ are distinct things.' You are wrong to admit ' $A$ is $B$, and $C$ is $B$ ' and not ' $A$ and $C$ are distinct things.' If the latter is false, then the first is false.

Pugg.- Is $A B$ ?

Ther.- It is not.

Pugg.- Is $C B$ ?

Ther.-Yes.

\footnotetext{
5 Then they have used the same reasoning where for 'material quality' they have substituted the following new items: feeling; perception; coefficients (sarikhāras); consciousness; the organ of sight; the organ of hearing; the organ of smell; the organ of taste; the organ of touch; visible object; sound; odour; taste; tangible object; mind (sensis communis); cognizable object; eye as subjective element; sights as subjective element; visual cognition as subjective element; ear as subjective element; sounds as subjective element; auditory cognition as subjective element; nose as subjective element; odours as subjective element; olfactory cognition as subjective element; tongue as subjective element; tastes as subjective element; gustatory cognition as subjective element; body as subjective element; touches as subjective element; tactile cognition as subjective element; mind as subjective element; mind-cognizing as subjective element; cognizables as objective element; eye as controlling power; ear as controlling power; nose as controlling power; tongue as controlling power; body as controlling power; mind as controlling power; female sex as controlling power; male sex as controlling power; life as controlling power; pleasure as controlling power; pain as controlling power; joy as controlling power; grief as controlling power; hedonic indifference as controlling power; faith as controlling power; energy as controlling power; mindfulness as controlling power; samādhi as controlling power; understanding as controlling power; the thought: "I shall come to know the unknown" as controlling power; the coming to know as controlling power; the having known as controlling power.
} 
Pugg.-- Is $C$ one thing and $A$ another?

Ther.-No, that cannot be truly said.

Pugg.-If ' $C$ is $B$ ', then you should also have admitted that ' $A$ and $C$ are distinct things.' You are wrong in admitting the truth of ' $C$ is $B$ ' while you deny that of ' $A$ is $B$.' If $A$ and $C$ are not distinct things, then $A$ is $B$. Thus, your position is false.

Symbolically:

Theravādin:

$((A \Rightarrow B) \&(C \Rightarrow B)) \Rightarrow(A \vee C) ; \neg(A \vee C)$

$\neg(A \Rightarrow B) \& \neg(A \Rightarrow C)$.

Nevertheless, it is an incorrect form. The logically corrected form is thus:

$((A \Rightarrow B) \&(C \Rightarrow B)) \Rightarrow(A \vee C) ; \neg(A \vee C)$

$\neg(A \Rightarrow B) \vee \neg(A \Rightarrow C)$.

Puggalavādin:

$(\neg(A \Rightarrow B) \&(C \Rightarrow B)) \Rightarrow(A \vee C) ; \neg(A \vee C)$

$(A \Rightarrow B) \& \neg(C \Rightarrow B)$.

It is an incorrect form, also. The logically corrected form is as follows:

$(\neg(A \Rightarrow B) \&(C \Rightarrow B)) \Rightarrow(A \vee C) ; \neg(A \vee C)$

$(A \Rightarrow B) \vee \neg(C \Rightarrow B)$.

We deal here with two modifications of modus tollens again and in the same manner the Theravādin and the Puggalavādin demonstrate that they do not know how implication can be verified. So, they apply different implications to infer contradictions, since they do not have a procedure for verifying conditional propositions as well as other propositions at all. The Theravādin is based on the scheme: 'If $A$ is $B$ and $C$ is $B$, then $A$ and $C$ are distinct things.' If it is false that ' $A$ and $C$ are distinct things,' then it is false that ' $A$ is $B$ and $C$ is $B$.' The Puggalavādin offers the following scheme: 'If $A$ is not $B$ and $C$ is $B$, then $A$ and $C$ are distinct things.' If it is false that ' $A$ and $C$ are distinct things,' then it is false that ' $A$ is not $B$ and $C$ is $B$.'

The main problem of the author(s) of the Kathavvatthu is that its author(s) does not know what the subject of logic is, but its subject is to infer automatically from premises which are verified as true sentences. In the Hindu terms, they do not know what pramāna (Sanskrit: 'means of knowledge') ishow we can verify sentences. Notice that an appropriate Pāli word pamāna occurs several times in the Pāli Canon, but never in the meaning of 'means of knowledge'. The teaching on pramāna appeared in India much later than all the texts of the Pāli Canon were composed. In this teaching all the sources of the true knowledge are classified: pratyakșa (Pāli: paccakkha; 'evidence,' 'first

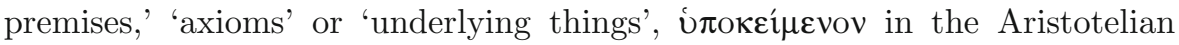
meaning), anumāna (Pāli: anumāna; 'inference'), upamāna (Pāli: upamāna; 'comparison,' 'analogy'), arthāpatti (Sanskrit: 'postulation, derivation from 
circumstances' there is not this word in the Pāli Canon), anupalabdhi (Sanskrit: 'non-perception, negative proof;' there is not a common word in the Pāli Canon, but in the Milindapañha (I.138) it is claimed that a real self is anupalabbhamāne —it is not being apprehended) and śabda (Pāli: sadda; 'word, testimony of past or present reliable experts'). In the European logic pramāna is a logical semantics and a logical epistemology, i.e. the rules of how to ascribe meanings to logical propositions.

The Theravādin as well as the Puggalavādin are not familiar with any logical semantics. Therefore, they cannot agree on using premises. They do not know how to verify or falsify atomic propositions and how to build up true composite propositions on the basis of atomic ones. Although they know some correct syllogisms, they have no idea how these syllogisms can be verified or falsified.

Hence, the Kathāvatthu cannot be evaluated as a logical treatise in fact. There is not even a hint of pramāna in this text. Meanwhile, there are many sophisms presented as true inference rules, such as:

Theravādin.-Is the concept of soul derived from feeling?

Puggalavādin.--Yes.

Ther.-Is the concept of good soul derived from good feeling?

Pugg.-Nay, that cannot truly be said [1, pp. 33-34].

Vedanam upādāya puggalassa paññattīti? Āmantā. Kusalam vedanam upādāya kusalassa puggalassa pañnattīti? Na hevam vattabbe ... pe ... (Kathāvatthu 192).

Ther.-If the concept of soul is derived from feeling, is the concept of bad soul derived from bad feeling?

Pugg.- Nay, that cannot truly be said [1, pp. 33-34].

Vedanam upādāya puggalassa pañ̃attīti? Āmantā. Akusalam vedanam upādāya akusalassa puggalassa paññattīti? Na hevam vattabbe ... pe ... (Kathāvatthu 193).

This text contains also a lot of references to authority (śabda of the nyāya) as an ultimate argument: 'it was not said by the Exalted One [A.Sch.-i.e. by the Buddha]' and 'it was said by the Exalted One.'

In the Kathâvatthu there is a dispute with, probably, a follower of an idea according to that all real things are momentary. In other words, the Sautrāntikas ('those who rely upon the sutras [A.Sch.- and avoid the Abhidhamma]') think that items can exist for only one instantaneous moment:

Controverted Point: That all things are momentary conscious units.

Theravādin: Do you imply that a mountain, the ocean, Sumeru chief of mountains, the cohesive, fiery, and mobile elements, grass, twigs, trees, all last only so long in consciousness? You deny... [1, p. 363].

Ekacittakkhanikā sabbe dhammāti? Āmantā. Citte mahāpathavī sanțhāti, mahāsamuddo sanțāti, sinerupabbatarājā sanțāti, āpo 
santhāti, tejo santhāti, vāyo santhāti, tinakațthavanappatayo santhahantiti? Na hevam vattabbe .. pe ... (Kathāvatthu 906).

This dispute is attributed to the 'Sautrāntikas' by the Pāli commentary, but it is unusual and unexpected, since the Sautrāntikas existed from the 2nd to the 3rd century A.D. in the Hellenized region of Gandhāra and they represented a North-Western branch of the Sarvāstivāda School whose ideas are contextually mentioned in the Kathāvatthu, also. The Sautrāntikas proposed the doctrine of momentariness (ksanikavāda) mentioned in the verse above. After the 4th century A.D. the Sautrāntikas were transformed into the Yogācāra School - the most influential school of Gandhāran Buddhism. The idea of extreme momentariness was then adopted by the greatest Buddhist logicians and epistemologists, such as Dignāga (ca. 480-540) and Dharmakīrti (ca. 600-660).

The disputation with, possibly, an intended Vaibhāśika-Sarvāstivādin is as follows:

Controverted Point: That a past or future experience is actually possessed.

Theravādin: But is not the past extinct, departed, changed, come to an end, finished? And is not the future unborn, not yet become, not come into being, not produced, not brought to pass, not manifested? How then can you call either something that is actually possessed? $[1$, p. 242].

Atītena samannāgatoti? Āmantā. Nanu atītam niruddham vigatam viparinatam atthangatam abbhatthangatanti? $\dot{\bar{A}}$ mantā. Hañci atītam niruddham vigatam viparịatam atthangatam abbhatthangatam, no ca vata re vattabbe - "atītena samannāgato"ti (Kathāvatthu 568).

The Vaibhāśikas represented a North-Eastern branch of the Sarvāstivāda School that took root in Kashmir from the 2nd to the 3rd century A.D.

Hence, the Kathâvatthu as one of the most important texts of the Abhidhamma of the Pāli Canon contained some disputes with the intended Sautrāntikas who had avoided the Abhidhamma as such and the Vaibhāśikas who had proposed another approach to the Abhidhamma which differs a lot from the Theravāda approach. Later, the Vaibhāśika ideas on the Abhidhamma were partly used in the Abhidharmakośa-bhassya - the greatest work written by Vasubandhu (ca. the 4th to the 5th century A.D.), who went on to be one of the most famous representatives of the Yogācāra School. Let us notice that Dignāga and Vasubandhu's texts are contained recently in the Tengyur, serving as the Tibetan Buddhist Canon.

To sum up, the logical fragments of the Kathâvatthu are not connected to the pramāna doctrine as a whole and then, most probably, they were transposed from disputes with some representatives of Northern Buddhism (e.g. the Gandhāran Buddhism), because the logic is applied in the Kathāvatthu mechanically, without understanding logical semantics or logical foundations. 
This feature distinguishes the Kathāvatthu from the Milindapañha, which proposes the four-step syllogisms, where the third step is used especially for verifying premises and inferences.

\section{Historical Context of Milindapañha}

The Milindapañha text is organized as a recorded conversation between the Buddhist monk Nāgasena and the Greek king Menander I Soter (Pāli:

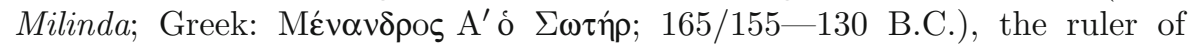
Arachosia, Gandhāra, Punjab, and Mathura (today's Afghanistan, Pakistan, Tajikistan, and some nothern states of India) [38]. It is worth noting that Greek clans/dynasties had ruled Bactria since the beginning of Alexander the Great's Indian campaign, i.e. since 326 B.C. First, they ruled this land as satraps of

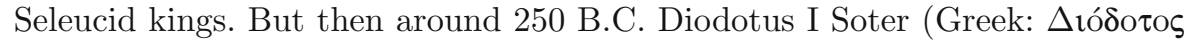
A' o $\Sigma \omega \tau \eta \dot{\rho})$, the governor of the Seleucid province of Bactria, proclaimed independence. Since that time, Greek kings advanced from Bactria in the east and south, taking control over Arachosia, Gandhāra, Punjab, and Mathura. Since ca. 130 B.C. the Greek clans mainly left Bactria, their homeland, and concentrated mostly in Gandhāra, where there was the capital of their Empire, Taxila. At the end, the Greek clans controlled only eastern Punjab and, probably, Strato III (Greek: $\Sigma \tau \rho \alpha ́ \alpha \omega v \Gamma^{\prime}$ ) was the last Greek king who ruled from ca. 25 B.C. to 10 C.E. So, the time of Menander was a culmination point of the Greek power in India. To sum up, from the time of Alexander the Great, the Greek rule in some parts of India took over ca. 336 years.

The people of the Greek dynasties (Pāli: Yona; Sanskrit: Yavana) were replaced by Indo-Scythians or Śakas (Sanskrit: Śaka) who at first continued the Greek Hellenization in India - at the beginning they continued to use the Greek language as official and to worship some Greek deities (Heracles, Zeus, Athena, Apollo and so on) [6,9]. At first, Śakas occupied Sogdiana and Greek Bactria, then Arachosia, Gandhāra, Sindh, Kashmir, Punjab, Haryana, Uttar Pradesh, Rajasthan, Gujarat, and Maharashtra. There were different IndoScythian clans - which were more or less Hellenized. The following two dynasties were the most powerful and, at the same time, the most Hellenized of the Indo-Scythian clans: (i) the Western Kșatrapas (ca. 35-400 A.D.) who ruled the western and central part of India (modern states of Gujarat, Maharashtra, Rajasthan, and Madhya Pradesh); (ii) the Kusāṇas (Bactrian: Kvpowo; Sanskrit: Kușāna) (ca. 35-375 A.D.) who at their peak ruled present-day Afghanistan, Pakistan, Tajikistan, south of Uzbekistan, and some northern parts of India up to Varanasi. But at the end of their power, the Kuṣānas controlled only eastern Punjab, while the Greeks controlled the same region at the time of the decline of their power 350 years previously.

Thus, the date of ca. 400 C.E. was an end of all Hellenized dynasties in India. The Western Kṣatrapas and the last Kuṣānas in eastern Punjab finally fell and their territories were invaded by the Gupta Empire. Quite later the Kidarites and Hephthalites expelled the Guptas and other clans from the territory once controlled by the Kusānas in their greatest period. The 
Hephthalites were primarily Zoroastrian in the Sassanian meaning-neither Hindu, nor Buddhist certainly.

Greek was used as an official language in Afghanistan, Pakistan, and the northern parts of India at least for three-four centuries; first of all, it was used for edicts, trading and receiving taxes. One of the taxable documents was found at Aï Khanum (today's Afghanistan) and it is dated to the 2nd century B.C. The writing appears only on its one side and it is made in black ink, presumably carbon-based. The writing material is prepared from skin. And this document is one of the oldest examples of texts on skin found until now in India. The text is as follows:

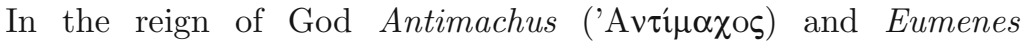

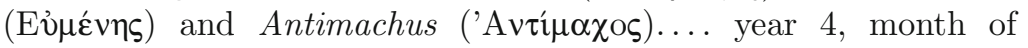
Olöus, in Asangorna(?), when NN was guardian of the law. Menodotus, tax-gatherer, in the presence of NN, who was sent out likewise by Demonax the former ..., and of Simus(?), who was ... by agency of Diodorus, controller of revenues, acknowledges receipt from(?) NN the son(?) of Dataes(?), ... of the payments due in respect of the purchase ... [25].

'God Antimachus' mentioned in the inscription is a Greco-Bactrian king,

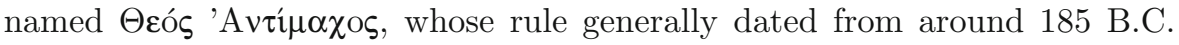
to 170 B.C. On the Indian coins like silver tetradrachms he was depicted by the diademed bust of king on the obverse. On the reverse of these coins there was the following inscription: BA $\Sigma \mathrm{I} \Lambda \mathrm{E} \Omega \Sigma$ $\Theta \mathrm{EOY} / / \mathrm{ANTIMAXOY}$, round the Greek deity Poseidon, standing to front, holding trident in right hand and palm in left hand $[14,17,29]$.

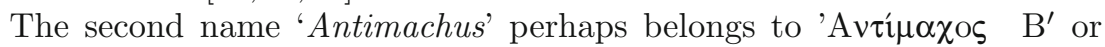

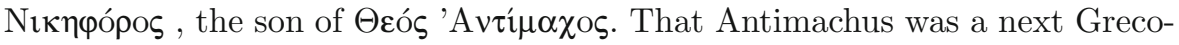
Bactrian king, who ruled on a vast territory from the Hindu-Kush to the Punjab around 170 B.C.

Since the territorial conquest of Arachosia, Gandhāra, Punjab, and Mathura by the Greek kings, there have been used the following two official languages: (i) Greek for edicts, trading, taxes and all other things related to secular and political matters; (ii) Gāndhārī (one of the Prakrits) in the Kharosthī script (this script is obviously of the Aramaic origin) just for religious matters: hymns and philosophy [38]. This was particularly visible on the Indo-Greek coins including the coins of Menander. On obverses we see usually a king portrate, a royal sign or a Greek deity with a Greek legend around it. On reverses we observe a Greek deity or a royal sign with a Gāndhārī legend in the Kharoșthī script $[14,17,29]$.

Please see the two examples of Menander's coin in Figs. 1 and 2. On the Indo-Greek coins we can find out sometimes some Buddhist symbols, also, such as dharmacakra (Pāli: dhammacakka). In Gandhāra there were built many Buddhist stūpas and temples by the Greeks: Dharmarajika stupa and monastery, Double-Headed Eagle Stupa and Apsidal Temple at Sirkap, etc. The Buddha was often depicted as a character accomponied by some Greek deities: first of all, by Heracles and Erotes (Cupids), see Figs. 3, 4 and 5. All these facts testify 


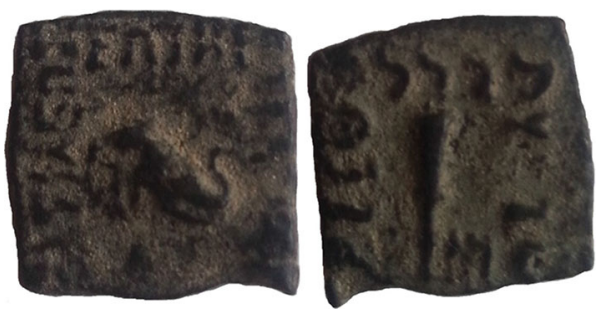

Figure 1. Menander I Soter square chalkous (160-130 B.C.). Obverse: head of elephant right wearing bell around neck, Greek legend around: BA $\Sigma \mathrm{I} \Lambda \mathrm{E} \Omega \Sigma / \Sigma \Omega$ THPO $\Sigma / \mathrm{MENAN} \Delta \mathrm{POY}$. Reverse: club of Heracles, monogram at right, Kharoșțī legend around: Maharajasa / tratarasa / Menamdrasa. Material: dark green patina. Weight: 1.7 gr. Size: $15 \times 15 \mathrm{~mm}$. The square coin reflects the preference of their Indian subjects for this shape, similar to the punchmarked coins of the Mauryan Empire

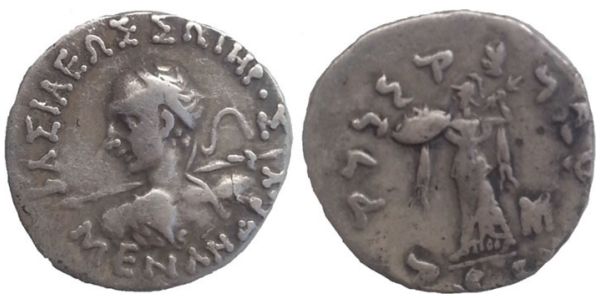

Figure 2. Menander I Soter silver drahm (160-130 B.C.). Obverse: diademed bust of king left, seen from behind, holding spear in thrust position in right hand, aegis on left shoulder, Greek legend around: BA $\Sigma \mathrm{I} \Lambda \mathrm{E} \Omega \Sigma \quad \Sigma \Omega \mathrm{THPO} \Sigma / / \mathrm{MENAN} \Delta \mathrm{POY} . \quad$ Reverse: Athena Alkidemos standing left, holding sloping shield on outstretched left arm, hurling thunderbolt with right hand, monogram at right, Kharoșthī legend around: Maharajasa tratarasa // Menamdrasa. Material: silver. Weight: 2.4 gr. Size: $17 \mathrm{~mm}$

to accepting the Buddhist doctrine by the Greeks before the growth of their Empire.

Hence, from the archeological point of view we can conclude that the Greek king Menander might have been a Buddhist follower in fact. The talking of Nāgasena to him was possible, indeed. The only problem is that this conversation should have been in Gāndhārī, not Pāli. Nevertheless, there were excavated some texts in Gāndhārī, such as Dhammapada, which are known to be written in Pāli, too. Therefore, the Milindapañha theoretically can be first 


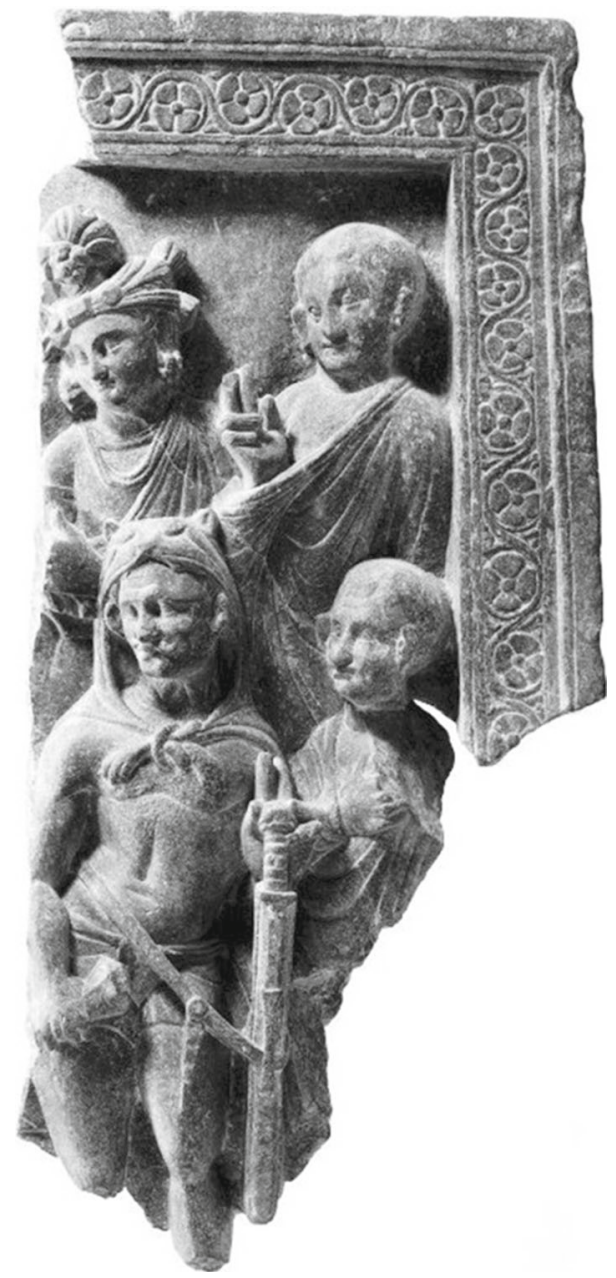

FiguRE 3. Fragment of a panel showing Vajrapāṇi (Heracles) and other figures attending the Buddha. Museum number: 1970,0718.1 British Museum. School/style: Gandhāra School. Culture/period: Kușāna. Date: 2nd century -3rd century A.D. Materials: schist. Technique: carved. Dimensions: $54 \mathrm{~cm}$ (height); $25 \mathrm{~cm}$ (width); $7.5 \mathrm{~cm}$ (thickness); $61.5 \mathrm{~cm}$ (height, with mount); $25 \mathrm{~cm}$ (width, with mount); $12.5 \mathrm{~cm}$ (thickness, with mount). Acquisition date: 1970. http://www. britishmuseum.org/

in Gāndhārī, in the sacral language of Greco-Buddhists, and then translated into Pāli. 


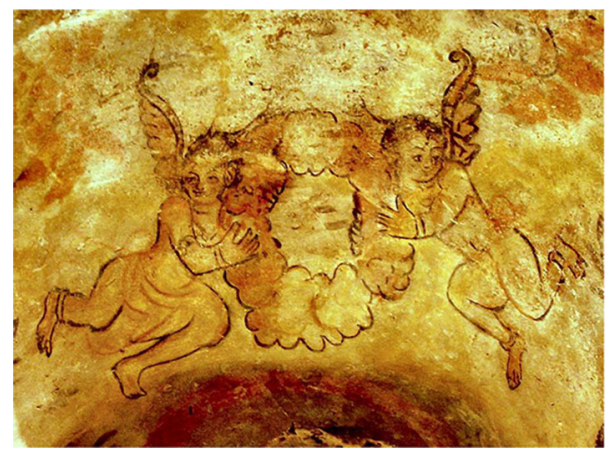

Figure 4. Winged Cupids holding a wreath over the Buddha. Museum number: MG21810 Musée Guimet. School/style: Gandhāra School. Culture/period: Kusānạa. Date: 3rd century A.D. Place: Tapa Kalan, Haḍa. Technique: painting. Acquisition date: La Délégation archéologique française en Afghanistan led by Jules Barthoux in 1926-1927. https:// commons.wikimedia.org/wiki/File:CupidsAndBuddha.JPG

The Bactrian Greeks were well educated and have contributed to a philosophical conversation on a Buddhist subject. So, in Aï Khanum there was found a philosophical dialogue (written on skin), close to some Buddhist matters: col. II.

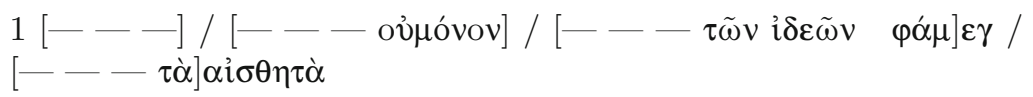

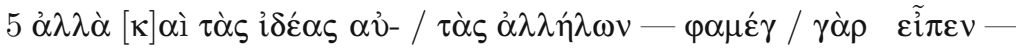

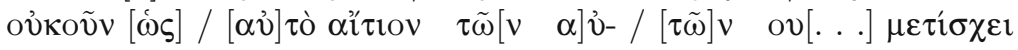

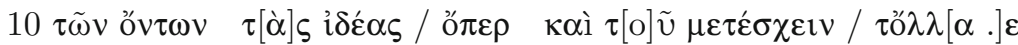

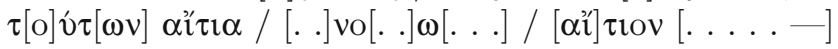

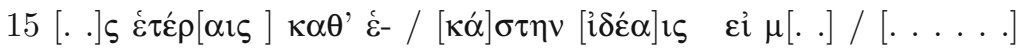
$\pi$ pòs $\tau[..] /[\ldots ..] \alpha[\ldots] \lambda \alpha /[\ldots \ldots] v \varepsilon 1 \delta[.] \omega v$

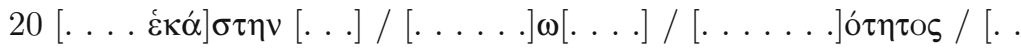
$\ldots \ldots ..] \pi \mathrm{o}[..] /[\ldots \ldots \alpha \boldsymbol{\alpha} \sigma] \theta \eta \tau \tilde{\omega} v$

$25[\ldots \ldots.] \alpha[.] \operatorname{ci\delta } \delta \tilde{\omega} v /[\ldots \ldots$.$] vovs$

col. III.

$1[---] /[-\longrightarrow] /[-\longrightarrow-] \dddot{\omega}[\sigma \tau] \varepsilon / \delta i \grave{\alpha}[\tau \circ \tilde{\tau} \tau \omega \nu \quad \tau] \tilde{\omega} \nu$ $[\alpha \tilde{v}] \tau \tilde{\omega} v$

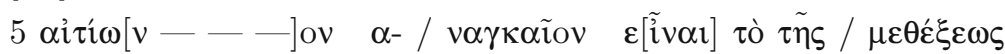

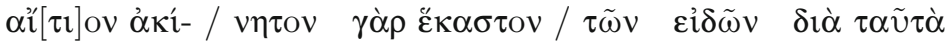

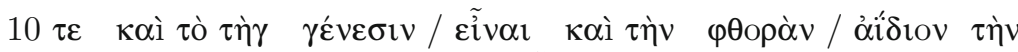

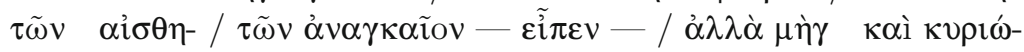

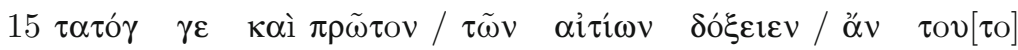

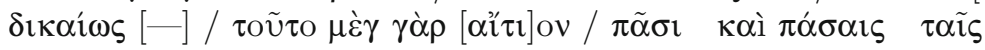




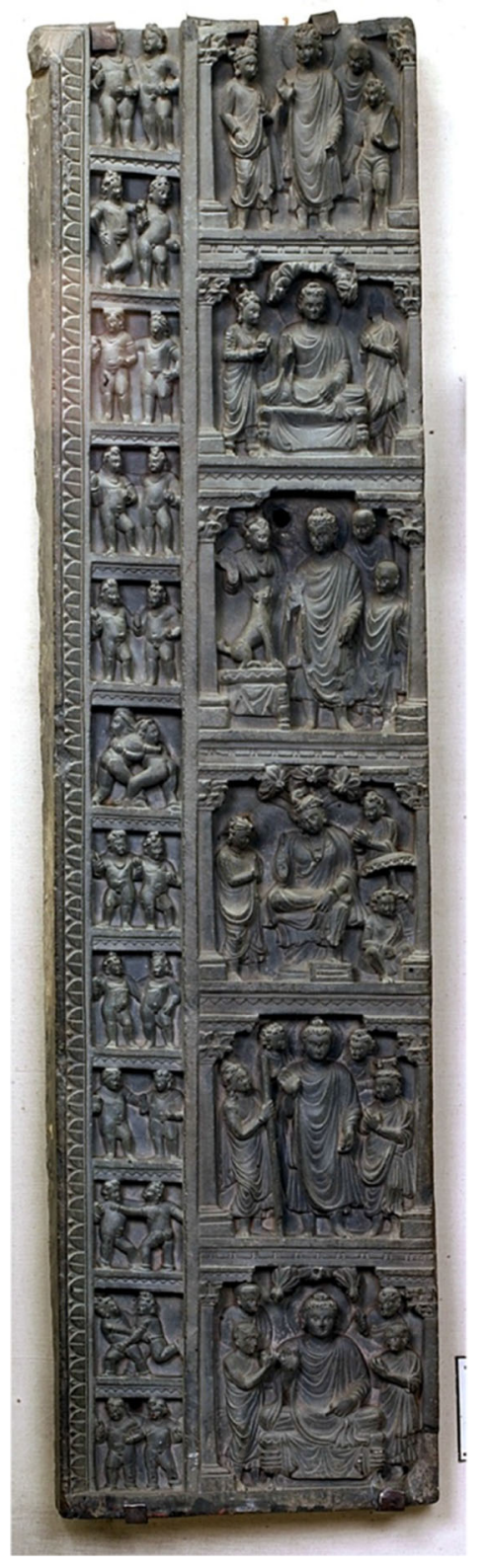

Figure 5. Stele with scenes from the life of the Buddha and playing Cupids. Museum number: G-109 Lahore Museum. School/style: Gandhāra School. Culture/period: Kușāna. Date: 3rd century A.D. Place: Pakhtunkhwa province. Materials: schist. Technique: carved. Dimensions: $118 \mathrm{~cm}$ (height); $13 \mathrm{~cm}$ (width); $8.5 \mathrm{~cm}$ (thickness). http://www.lahoremuseum.gov. pk 


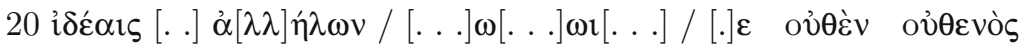
$\tau[.] /[. ..] \varepsilon \imath[.] \alpha \rho[\ldots . ..] /[\ldots . ..] \alpha \cup \jmath \tau \omega[.--$

$25[.] \varepsilon[.] \varepsilon \imath{ }^{\circ} \quad \tau \omega[. .-] /[. ..] \omega \nu \quad \kappa[.--] /[.] \ldots[. .--] /[$.

$---]$

col. IV.

$1[.] \varepsilon \varepsilon[\ldots . . .--] / \tau[. ..] \alpha \lambda \lambda[.] \lambda[.--] /[. ..] \mu \varepsilon \rho[.] \nu \omega[. .-]$

$/[..] \nu \varepsilon[.] \tau \alpha \xi[.] \mu \varepsilon[. .--]$

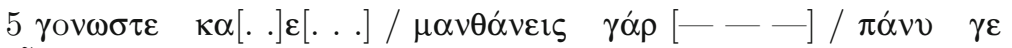

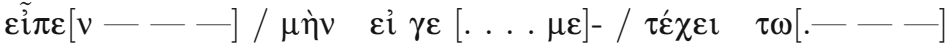

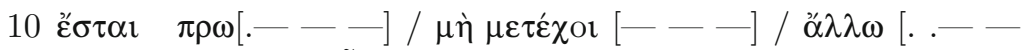

$-] / \lambda[\ldots--] / \varepsilon \tilde{i} \pi[\varepsilon \nu---]$

$15 \tau[---]$

[24].

This text contains some abstract notions such as 'ideas' (i $\delta \varepsilon \dot{\varepsilon} \alpha \varsigma)$ ), 'reason'

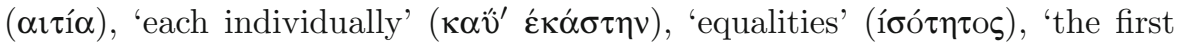
reason of reasons' $(\pi \rho \tilde{\omega} \tau$ ov $\tau \tilde{\omega} v$ ai $\tau i \omega v)$, etc. Also, there is the following

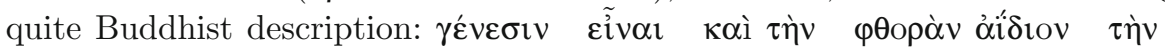

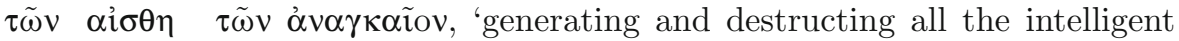
entities are forever,' which hints at the wheel of reincarnation. The phrase 'nothing of nothing' (oúvícv oúvívós) hints at the concept of śūnyatā. So, the Early Buddhism influences on this text are not excluded. Then this text is the earliest eclectic document of Greco-Buddhism.

Till now we have no archeological evidences of a direct Greek influence on Nyāya, but there are some direct evidences of their impact on astrology and geometry in India. So, in Buddhist inscriptions, written in the Kharoșthī script and in the Gāndhārī language, excavated in Gandhāra, and dated to from the 1st century A.D. to the 3rd century A.D., the following eight Greco-

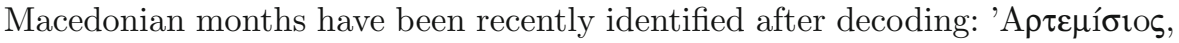

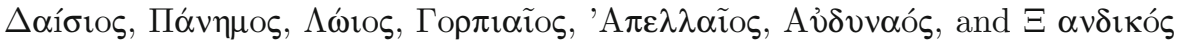
[27]. It means that at that time the Greco-Macedonian calendar and astrology was accepted by the Gandhāran Buddhists.

In Medieval Hindu astrology there were some loanwords from Greek: (i)

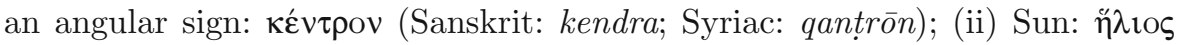

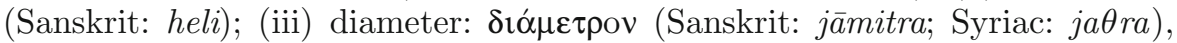

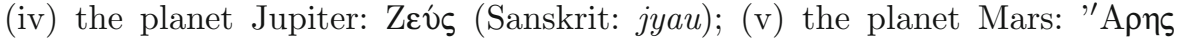
(Sanskrit: $\bar{a} r a$ ), etc. More technical terms: (i) a succedent house: epanaphora (in Greek), panaphara (in Sanskrit); (ii) a cadent house: apoklima (in Greek), apoklima (in Sanskrit); (iii) a void of course Moon: kenodromia (in Greek), kemadruma (in Sanskrit); (iv) an application: sunaphe (in Greek), sunapha (in Sanskrit); (vi) the $10^{\circ}$ segments of the ecliptic: dekanos (in Greek), drekanas (in Sanskrit), etc.

In the Yavanajātaka (one of the first books on Hindu astrology that was written by a Greek author, 'Yavana') reconstructed by David Pingree $[21,22]$, we can observe some Greek patterns of thinking, e.g. a mathematical 
calculation is called 'inference' (anumāna), although in the Hindu tradition mathematics was never based on logic:

One should find that the number of (lapsed) tithis diminished by the number of lapsed avamas equals the number of (civil) days which have passed in the yuga. There is a seven-fold measure of the planetary week-days; in seeking the answer to this, one desires (the use of) inference (anumāna) ([22], vol. 1).

The Yavanajātaka was a translation from a book written first in Greek and devoted to astrology, and it is considered that this translation was made in the Western Kșatrapa Empire in the 2nd century A.D. by Yavaneśvara and versified by Sphujidhvaja in the 3rd century A.D. [21].

The Greek culture had an effect, first of all, on the social organization of communities in Bactria and Gandhāra. Therefore, in the Gāndhārī language there were some administrative terms loaned from Greek, e.g.: (i) stratega 'general, commander' ( $\sigma \tau \rho \alpha \tau \eta \gamma o ́ \varsigma)$; (ii) meridarkha 'meridarch' ( $\varepsilon \rho 1 \delta \alpha \rho \chi \eta)$, etc.

As I said above, the Western Kṣatrapas and the Kusānas continued the Greek Hellenization of India [12,33]. Nevertheless, they stopped using the Greek language officialy in the 1st-2nd century A.D., but continued to use the Greek alphabet: the Western Kṣatrapas for a Prakrit and the Kuṣānas for Bactrian. There was found the Rabatak inscription of 127 A.D. that contains a very important statement concerning the change of the official language in the Empire from the Greek language to the Bactrian one. So, Kanișa the Great

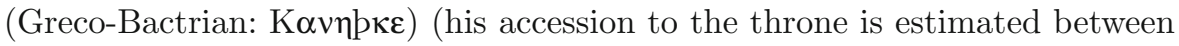
ca. 90 and 140 A.D.) was the first who replaced the use of Greek by the "Aryan" language after the 400-years history of the Greek and Greco-Scythian communities in the North-West of India. In fact, this "Aryan" language was Bactrian - one of the Old-Iranian dialects with many loanwords from Greek. The fragment of this Edict:

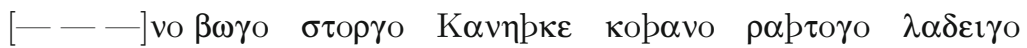

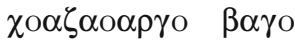

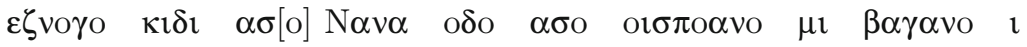

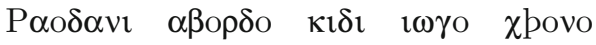

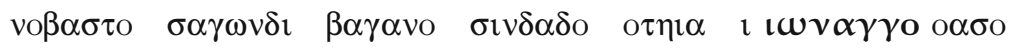

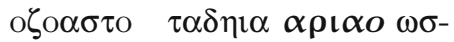

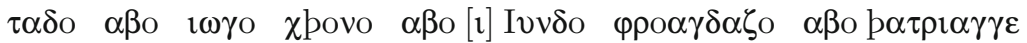

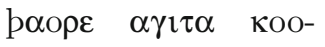

$\alpha \delta \eta \alpha$ о о $\delta$ o $1 \omega \zeta$ เ

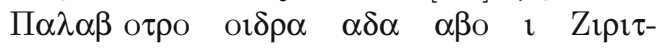
[34].

1-3 The year one of Kaniska, the great deliverer, the righteous, the just, the autocrat, the god, worthy of worship, who has obtained the kingship from Nana and from all the gods, who has laid down (i.e. established) the year one as the gods pleased. 
3-4 And it was he who laid out (i.e. discontinued the use of) the Ionian speech and then placed the Arya (or Aryan) speech (i.e. replaced the use of Greek by the Aryan or Bactrian language).

4-6 In the year one, it has been proclaimed unto India, unto the whole realm of the governing class including Koonadeano (Kaundinya) and the city of Ozeno (Ozene) and the city of Zageda (Saketa) and the city of Kozambo (Kausambi) and the city of Palabotro (Pataliputra) and so long unto (i.e. as far as) the city of Ziri-tambo (Śri-Campa) [18].

Since that Kaniska edict, the Bactrian language in the Greek script has been used as official for many centuries, even at the Hephthalite time there were some inscriptions in Bactrian. So, many legal documents in Bactrian are found, including (i) the judgments concerned with the sale of agricultural lands, deeds of manumission, and undertakings to solve conflicts; (ii) the land sale contracts written in two copies, an upper and a lower copy, usually on the same sheet; (iii) the tax receipts presented by storekeepers and millers to the people who had brought in goods. These documents were composed on skin in the way the Greeks had done before [35]. Also, there are some Buddhist texts in Bactrian in the Greek script, made on skin which is untypical for the Indian civilization as such [36].

The main feature of Indian culture is that there is a huge gap and contrast between the traditional Sanskrit texts and the Indian archeology. On the one hand, many descriptions, such as the Mahābhārata, are not confirmed by archeology at all. On the other hand, archeological data reconstructed after excavations have no parallel in Sanskrit texts. For instance, it is unclear why the Buddha was often accompanied by Cupids, see Figs. 4 and 5. What was the tantra for these images?

Hovewer, in the case of the Pāli tradition the phenomenon of GrecoBuddhism in Gandhāra is confirmed textually. This fact supports the authenticity of the Milindapañha - in the meaning that this text was created in Gandhāra indeed. In Sanskrit there are no phrases on Yavanas in respect to their Buddhist faith. In contrast, the Mahāvamsa or the Great Chronicle of Sri Lanka, composed in Pāli in the late 5th or early 6th century A.D., mentions 'Yonas' (the Greeks) as Buddhists many times. In particular, in this book, there is a description how Aśoka (ca. 268 B.C. to 232 B.C.), the great Indian emperor of the Maurya Dynasty, has supported Moggaliputta-Tissa (ca. 327 B.C. -247 B.C.), his advisor and spiritual teacher, in organizing the Second Buddhist Council and sending theras to the following countries, among which there are mentioned Yona (Greco-Bactria), Kasmīra (Kashmir), and Gandhāra, where later the Greco-Buddhism was founded:

When the thera Moggaliputta, the illuminator of the religion of the Conqueror, had brought the (third) council to an end and when, looking into the future, he had beheld the founding of the religion in adjacent countries, (then) in the month Kattika he sent forth theras, one here and one there. The thera Majjhantika he sent to Kasmīra 
and Gandhāra, the thera, Mahādeva he sent to Mahisamandala. To Vanavāsa he sent the thera named Rakkhita, and to Aparantaka the Yona named Dhammarakkhita; to Mahārațtha (he sent) the thera named Mahādhammarakkhita, but the thera Mahārakkhita he sent into the country of the Yona. He sent the thera Majjhima to the Himalaya country, and to Suvannabhūmi he sent the two theras Sona and Uttara. The great thera Mahinda, the theras Itțhiya, Uttiya, Sambala and Bhaddasāla his disciples, these five theras he sent forth with the charge: 'Ye shall found in the lovely island of Lañkā the lovely religion of the Conqueror' [8, p. 82].

This quote is especially interesting, as the 'Yona named Dhammarakkhita,' i.e. a Greek, is been mentioned among the important Buddhist leaders and teachers at the time of Aśoka (the 3rd century B.C.). This is quite early, because the Greeks had come to the region of India only since the Indian campaign of Alexander the Great, starting in 326 B.C.

It is said further that the mission of Maharakkhita was really successful among the Greeks of Greco-Bactria:

The wise Maharakkhita who went to the country of the Yona delivered in the midst of the people the Kalakarama-suttanta [A.Sch.the Kālakārāmasutta, Ariguttara-nikāya 4.24]. A hundred and seventy thousand living beings attained to the reward of the path (of salvation); ten thousand received the pabbajja [8, p. 85].

The next significant evidence in the Mahāvamsa about the Greco-Buddhists and their influence and spiritual power among all the Buddhist communities is as follows. One Sinhalese king of Sri Lanka, called Dutthagāmaṇi or Gāmaṇ̄ Abhaya ('fearless Gamini'), who reigned from 101 B.C. to 77 B.C., decided once to build up the Great Stūpa (Pāli: thūpa) that is known now as the Ruwanweliseya and Swarnamalee Chetiya and in order to celebrate the festival devoted to opening the Thūpa he invited many hundred thousand representatives of Buddhist communities from different places, including Kasmīra (Kashmir), Alasanda (the Greek city of Alexandria, a capital of Bactria), Pallavabhogga (Wilhelm Geiger means that it is Persia, but it is, most likely, Margiana in today's Afghanistan):

From various (foreign) countries also did many bhikkhus come hither; what need to speak of the coming of the brotherhood living here upon the island? With eighty thousand bhikkhus from the region of Rajjagaha came the thera Indagutta, the head of a great school. From Isipatana came the great thera Dhammasena with twelve thousand bhikkhus to the place of the cetiya.

With sixty thousand bhikkhus came hither the great thera Piyadassi from the Jetārāma-vihāra. From the Mahāvana (monastery) in Vesāl̄ came the thera Urubuddharakkhita with eighteen thousand bhikkhus. From the Ghositārāma in Kosambī came the thera Urudbammarakkhita with thirty thousand bhikkhus. From the 
Dakkhịāgiri in Ujjen̄̄ came the thera Urusamgharakkhita with forty thousand ascetics.

With a hundred and sixty thousand bhikkhus came the thera named Mittiṇṇa from the Asokārāma in Pupphapura. From the Kasmīra country came the thera Utịnna bringing with him two hundred and eighty thousand bhikkhus. The wise Mahādeva came from Pallavabhogga with four hundred and sixty thousand bhikkhus, and from Alasanda the city of the Yonas came the thera Yonamahādhammarakkhita with thirty thousand bhikkhus [A.Sch.-Yonanagarā'lasandāso, yona mahādhammarakkhito; Thero timssa sahassāni, bhikkhū ādāya āgamā.].

From his dwelling by the road through the Viñjhā forest mountains, came the thera Uttara with sixty thousand bhikkhus.

The great thera Cittagutta came hither from the Bodhimandavihāra with thirty thousand bhikkhus. The great thera Candagutta came hither from the Vanavāsa country with eighty thousand ascetics. The great thera Suriyagutta came from the great Kelāsavihāra with ninety-six thousand bhikkhus. As for the number of the bhikkhus dwelling in the island who met together from every side, no strict account has been handed down by the ancients. Among all these bhikkhus who were met in that assembly those alone who had overcome the āsavas, as it is told, were ninety-six kotis.

These bhikkhus stood according to their rank around the place of the Great Thūpa, leaving in the midst an open space for the king [8, pp. 193-194].

So, in this narration we are reading how the 30 thousand Greco-Buddhists came from Bactria to take part in the festival at Sri Lanka. We should pay attention that Duṭthagāmaṇ̄ who organized this festival was almost a contemporary of the same Menander, the king of Greco-Indian Empire with the capital in Gandhāra who became one of the two main characters of the Milindapañha. Due to coins and other archeological facts, we know also that Menander as well as the majority of Hellenized elite of Greco-Bactria at that time or even earlier converted to Buddhism.

If we trust the Mahāvamsa, then the Greco-Buddhists can have influenced the Pāli Buddhists (Theravādins) since the 3rd century B.C.

As a consequence, the Milindapañha can be a result of direct influences from Gandhāra, indeed: there are some old narrations in Pāli about close contacts among the Pāli theras and the Bactrian-Gandhāran Greco-Buddhists at the time of Menander.

The sacred language of the theras of Sri Lanka was Pāli, while the sacred language of the Greco-Buddhists was Gāndhārī. In the Mahāvamsa, it is stated that the Pāli Canon was first written down at the time of the ruler of Sri Lanka, Vatțagāmaṇi Abhaya (reigned from 29 B.C. to 17 B.C.), and due to his direct support: 
He (the king) built the cells of the vihara so that a greater number were joined together, for he reflected: 'In this way it will be possible to restore them.'

The text of the three pitakas and the atthakathā thereon did the most wise bhikkhus hand down in former times orally, but since they saw that the people were falling away (from religion) the bhikkhus came together, and in order that the true doctrine might endure, they wrote them down in books.

Thus did the king Vatțagāmaṇi Abhaya reign twelve years, and, at the beginning, five months beside [8, p. 237].

This event is traditionally interpreted as the so-called Third Buddhist Council that was held in Sri Lanka in the late 1st century B.C. However, it is known that there was another concurrent Third Buddhist Council that held in Kashmir (Sanskrit: Kaśmīr) from the late 1st century A.D. to the early 2nd century A.D. and this council was supported by the emperor of the Kuṣāna dynasty, Kanișka the Great:

Lately the king, Kanișka, with the honourable Pārśvika, summoning a council of five hundred saints and sages in the country of Kaśmīr, they drew up the Vibāshā Sāstra. These were the five hundred bats who formerly dwelt in that decayed tree [4, p. 117].

The centre of the Kuṣāna Empire was located in Gandhāra and the political elite of this empire remained Hellenized still [2]. At the sites of Bactria and Gandhāra there were excavated many fragments of the Buddhist manuscripts dated from the 1st to the 5th century A.D. and these texts were written in Gāndhārī and Bactrian. As a consequence, we can assume that during the Third Buddhist Council in Kashmir the Gāndhārī Canon was founded as a parallel to the existed Pāli Canon. It is an evidence that the Greco-Buddhism was really influential at that time and the Milindapañha can have appeared due to some borrowings from the Gandhāran Buddhism in fact.

There is else another fact supporting the authenticity of the Milindapañha. In ca. 400 A.D., all the Hellenized Śaka dynasties (the Western Kṣatrapas and the Kuṣānas) fell. But they had sponsored Buddhism and after their fall Buddhism in India faced many troubles: a lot of monasteries were closed and many Buddhist temples were transformed into Hindu temples, first of all into Shaivite ones. Archeologically, it can be readily seen that Buddhist images started to be replaced by Hindu deities since 400 A.D. and Shaivism became especially popular in the Buddhist regions, such as Kashmir. At the same time, Shaivism extended through the Gupta Empire and became popular among the Tamils, as well.

Since then all mentions of the Greeks (Yavanas) and Indo-Scythians (Śakas) and all attitudes towards them in Sanskrit were extremely negative. The Yavanas and Śakas are characterized as Kṣatriyas who have fallen to the level of Śudras or even should be regarded as outcaste:

śanakais tu kriyālopād imāh kṣatriyajātayah / 
vrșalatvam gatā loke brāhmanādarśanena ca // paundrakāś codadravidāh kāmbojā yavanāh śakāh /

pāradāh pahlavāś cīnāh kirātā daradās tathā //

(Mānavadharmaśāstra 10, 43-44; [32])

By neglecting rites and by failing to visit Brahmins, however, these men of Kșatriya birth have gradually reached in the world the level of Śūdras - Punḍrakas, Coḍas, Draviḍas, Kāmbojas, Yavanas, Śakas, Pāradas, Pahlavas, Cinnas, Kirātas, and Daradas [20].

From this it follows that the Milindapañha cannot be written after 400 A.D.in an atmosphere of hatred in relation to the Yavanas and Śakas [13]. Most probably, taking into account the historical context considered above, this text should have appeared between 130 B.C. and 120 A.D., i.e. between the time of Menander and the time of Kaniska the Great.

Before the date of 400 A.D. the Greeks were considered a prestigious caste within the Kșatriyas who patronate Buddhism. So, the word Yavana or Yona often occurs among names of donators at Junnar, Karla, Nasik, and Junagadh caves (the territory controlled by the Western Kșatrapas). For instance, the Karla cave:

dhenukākața yavanasa sihadhayāna thambho dānam

(This) pillar (is) the gift of the Yavana Sihadhaya from Dhenukākața [30].

Another example from the same cave:

1. umēhanākața yavanasa 2. vitasa $\left[m^{*}\right]$ gatānam dānam thabho

(This) pillar (is) the gift of the Yavana Vițasamgata from Umēhanākața [42].

The Nashik cave:

1. sidham் otarāhasa dātāmitiyakasa yonakasa Dhaṁmadevaputasa

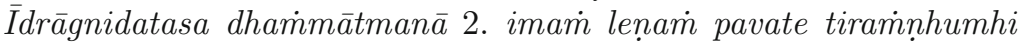

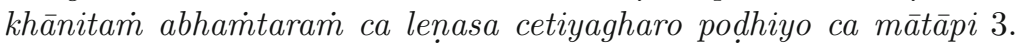
taro udisa ima lena kāritam savabudha-pujāya cātudiśasa bhikhūsamighasa niyātitam sa 4 . ha putena Dhammarakhitena

Success! (The gift) of Indrāgnidatta, son of Dhammadeva, the Yavana, a northerner from Dattāmitrī. By him, inspired by true religion, this cave has been caused to be excavated in mount Tiranhu, and inside the cave a Caityagṛha and cisterns. This cave made for the sake of his father and mother has been, in order to honour all Buddhas, bestowed on the universal Samgha of monks, together with his son Dhammarakhita [30].

Let us pay attention that a Greek donator is designated in these inscriptions in the following two forms: either yonakasa (the plural Prakrit form) or yavanasa (the plural rather Sanskrit form). In these caves, only the class of Greek men has a plural form to desigate its singular representative. There is only one other class of people, who is mentioned in the plural form, too, it 
is a class of religious leaders, such as theras. Hence, the plural form is used rather to express a deep respect to a man. Therefore, we can assume that the word yavanasa (or yonakasa) was used in these inscriptions to indicate a prestigious caste of Greeks. Since 400 A.D. it would be impossible absolutely. It is worth noting that in the Milindapañha, it is assumed that yonaka (i.e. yonakasa or yavanasa) is the highest varna. This statement is drawn from the following order of varnas: Yavanas (yonaka), Kṣatriyas (khattiya), Brāhmanas (brāhmana), Vaiśyas (gahapati), please see:

yonaka sukhumāliniyopi khattiya sukhumāliniyopi

brāhmanasukhumāliniyopi gahapati sukhumāliniyopi (Milindapañha 3.4.6).

Thus, the Milindapañha is an authentic book, indeed: first, Menander (one of its two main characters) was real; second, its narrative satisfies all the historical contexts, e.g. to be yavanasa before the 2nd century A.D. was honorable for Buddhist communities in fact.

\section{The Proto-Nyāya Doctrine of pramāna in the Milindapañha}

Let us show now that the Milindapañha or the Questions of King Milinda contains some obvious contextual references to the pramāna teaching. The monk bearing the name of Nāgasena has talked to the Greek king Menander I Soter, the ruler of Indo-Greek Empire, and he has explained before Menander all the aspects of Buddhism by using different syllogisms.

One of the main differences of the Milindapañha and its syllogisms from the Kathāvatthu and its syllogisms is that each premise used for drawing conclusions and mentioned in the Milindapañha has or supposes an illustration to give a verification. Let us provide an example from this text:

The King said: 'Revered Nāgasena, have you seen the Buddha?'

'No, sire.'

'Then have your teachers seen the Buddha?'

'No, sire.'

'Well then, revered Nāgasena, there is no Buddha.'

'But have you, sire, seen the river Ūhā in the Himalayas?'

'No, revered sir.'

'Then has your father seen it?'

'No, revered sir.'

'Well then, sire, there is no river $\overline{\mathrm{U} h} \overline{\mathrm{a}}$ '

[10, vol. 1, p. 95].

In this fragment, Menander affirms that the Buddha does not exist, because he has not been seen by Nāgasena or his teachers, i.e. he is not given by our perceptions in the meaning of pratyakșa ('underlying things,' 'evidence') of the Nyāya philosophy. However, Nāgasena exemplifies by illustration that there is a knowledge that is obtained by inferences in the meaning of anumāna 
of Nyāya. For instance, as he said further, if somebody sees a pleasant city, well planned out, he knows just by inference, how great the founder was, but he has never seen this founder. Hence, the knowledge that the Buddha exists (existed) is given by inference, not perception. And Nāgasena appeals to this term, anumāna, to prove the Buddha's existence.

It is worth noting that according to Dignāga there are only the following two real sources of knowledge: pratyaksa ('evidence'; Pāli: paccakkha) and anumāna ('inference'). This thesis is assumed in the Milindapañha, also. For instance, the existence of the Buddha is deduced and in this deduction we do not need recourse to śabda ('authority') or perception. So, the author of the Milindapañha is focused on the problem of the Buddha's existence to show that there are the two sources of our knowledge: perception and inference, e.g. the Buddha is not given to our perception, but he is deduced logically.

The term of paccakkha occurs quite often in the Pāli Canon, but never in the logical meaning of the Nyāya philosophy. In most cases, its meaning is 'this is evident' or 'this is known.' For instance:

At Savatthi. "Bhikkhus, I will teach you the all. Listen to that...

"And what, bhikkhus, is the all? The eye and forms, the ear and sounds, the nose and odours, the tongue and tastes, the body and tactile objects, the mind and mental phenomena. This is called the all.

"If anyone, bhikkhus, should speak thus: 'Having rejected this all, I shall make known [paccakkhāya] another all' — that would be a mere empty boast on his part. If he were questioned he would not be able to reply and, further, he would meet with vexation. For what reason? Because, bhikkhus, that would not be within his domain" [5, vol. 2, p. 1140].

Sāvatthinidānam. "Sabbam vo, bhikkhave, desessāmi. Tam suñātha. Kiñca, bhikkhave, sabbam?? Cakkhuñceva rūpā ca, sotañca sadd̄̄

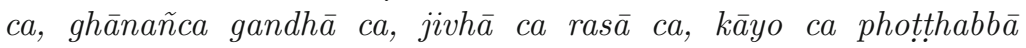
ca, mano ca dhammā ca-idam vuccati, bhikkhave, sabbam. Yo, bhikkhave, evam vadeyya: 'ahametam sabbam paccakkhāya aññm sabbam paññapessāmì'ti, tassa vācāvatthukamevassa; puttho ca na sampāyeyya, uttariñca vighātam āpajjeyya. Tam kissa hetu? Yathā taṃ, bhikkhave, avisayasmin"ti (Saṃuttanikāya, 1 Salāyatanasamyuttam 23 [Sabbasuttam $])$.

In the Kathâvatthu, premises involved in reasoning are not evident (in the common meaning as well as in the meaning of the nyāya word pratyaksa), i.e. their semantics remains unclear for us. In both the nyāya logic and in the Buddhist logic, well-expressed by Dignāga and Dharmakīrti, there is a requirement to illustrate reasoning by an example. This requirement to give an illustration is called udāhārana in Sanskrit. The comparison between the axiom, upanayana (observed phenomenon), and the provided example is called upamā. In turn, the comparison allows us to generalize the reason or condition for the observed 
phenomenon that is called hetu and to draw a conclusion that is called nigamana, by which we have applied the condition to the observed phenomenon to explain the latter. Let us consider the following classical example of the Hindu logic, also found in Mahāyānist logic:

(1) The udāhārana:

Yo yo aggimā so so dhūmāva.-Whatever is fiery, is smoky.

(2) the upamā (metaphor) may be introduced:

Smoky like a hearth.

(3) The upanayana:

Ayam pabbato dhūmāva.-This hill is smoky.

(4) The niggamana:

Tasmādayam aggima.-Therefore it is fiery.

(5) Smoky in (1), (2), and (3) is the hetu (condition or reason).

This reasoning differs a lot from all the syllogisms of the Kathāvatthu, because it assumes a verification procedure by udāhārana and upamā, i.e. by an illustration and example, respectively.

Let us notice that the term udāhārana as a requirement to give an example in proofs occurs in the Milindapañha among the standard terms naya and hetu denoting logical reasoning as such:

And those monks, sire, who teach and recite, speak and repeat the nine-limbed speech of the Buddha in its literal senses and developed meanings, with its methods and reasons and causes and examplesmonks such as these, sire, are called sellers of Dhamma in the Lord's City of Dhamma [10, vol. 2, p. 197].

Ye pana te, mahārāja, bhikkhū navaìgam buddhavacanam atthato ca byañjanato ca nayato ca kāranato ca hetuto ca udāharanato ca vācenti anuvācenti bhāsanti anubhāsanti, evarūp $\bar{a}$ kho, mahārāja, bhikkhū bhagavato dhammanagare 'dhammāpanikā'ti vuccanti (Milindapañha 5.4.1).

However, instead of udāhārana and upamā mentioned in the introducing words of the Milindapañha, in the main body of the book the author just uses one term denoting a requirement to give illustrations and examples-opamma that is exposed in the very beginning of the text:

Plunging into Further-Dhamma and Vinaya, deliberating the net of the Suttas,

Nāgasena's talk was varied with similes and in the method.

Aspiring to knowledge herein while gladdening the mind,

Hearken to the abstruse questions, dissipating occasions for doubt [10, vol. 1, p. 1].

\section{Abhidhammavinayogā $\bar{l} \overline{\bar{a}}$,}

suttajālasamattitā;

Nāgasenakath $\bar{a}$ citr $\bar{a}$,

opammehi nayehi ca. 
Tattha ñānam paṇidhāya,

hāsayitvāna mānasam;

Suṇātha nipune pañhe,

kanikhātțhānavidālaneti

(Milindapañha 1.1.1).

Also, it is important to point out that 'fiery' is regarded as a sample for hetu in the Milindapañha:

"Suppose, sire, there were no (lower) piece of wood for making fire, no twirling-stick, no cord for the twirling-stick, no upper piece of wood for making fire, no little piece of cloth (for tinder), and no proper effort on the part of a man-would a fire be produced?"

"O no, revered sir."

"But if, sire, there were a (lower) piece of wood for making fire, a twirling-stick, a cord for the twirling-stick, an upper piece of wood for making fire, a little piece of cloth, and proper effort on the part of a man-would that fire be produced?" "Yes, revered sir, it would be produced" [10, vol. 1, pp. 74-75].

Later this 'fiery' became classical for the Hindu logic. It turned into the most popular example for hetu in the Indian thought.

Hence, the Milindapañha is the only book of the whole Pāli Canon where we can find some references to a true proto-Nyāya logic with a kind of semantics. Nevertheless, this 'Hindu' logic of the Milindapañha is much more archaic than the logic of the Nyāya Sütra, because it only contains hints of the following two pramāna: paccakkha ('evidence') and anumāna ('inference'), and instead of the two ways of verification called udāhārana and upamā there is just one way for verification called opamma. The existence of the Buddha is the main example for anumāna provided in the Milindapañha. It is quite surprising, as his existence is not established by authority, which is what might be expected, but by inference, just logically.

In the Milindapañha, as well as it being in accordance with Dignāga's doctrine, all the first data are being collected by the pratyaksa or paccakkhaevidences. In the Pāli text, this mechanism of collecting facts is quite sophisticated and it corresponds to the Pāli abhidhamma that may be considered the Buddhist way to epistemology. There are the following five means of sense: 'eye-door' (cakkhu-dvāra); 'ear-door' (sota-dvāra); 'nose-door' (ghāna-dvāra); 'tongue-door' (jivhā-dvāra); 'body-door' (kāyadvāra). These five groups of the characteristic marks of individuality (up $\bar{a} d \bar{a} n a k k h a n d h \bar{a}$ ) are united in a form of object (rupakkhandh $\bar{a}$ ). This form can give rise to sensory contact, leading to feeling $(v e d a n \bar{a})$. Due to this, we can develop an idea of object (sañña). From this, some mental potentialities or conditions (sanikhāra) can grow up. At the end, a consciousness (viññana) takes all this in:

And again, sire, the cat seeks after its food only in what is near; even so, sire, the yogin, the earnest student of yoga must dwell beholding the rise and fall among the five groups of grasping, thinking: 'This 
is material shape, this the arising of material shape, this the going down of material shape; this is feeling, this the arising of feeling, this the going down of feeling; this is perception, this the arising of perception, this the going down of perception; these are the habitual tendencies, this the arising of the habitual tendencies, this the going down of the habitual tendencies; this is consciousness, this the arising of consciousness, this the going down of consciousness.' This, sire, is the second quality of the cat that must be adopted. And this, sire, was said by the Lord, the deva above devas:

"One should not be far from here (or) how will one produce the Acme of Becoming?

In the actual present, know your own body" [10, vol. 2, p. 269].

This epistemology is very similar to the transcendental-phenomenological reduction proposed by Edmond Husserl (1859-1938) so much later: we should start with analyzing pure phenomena and, as a result, we move to ourselves. ' $Z$ u den Sachen selbst' (go back to pure items as go home to ourselves) was an appropriate famous philosophical motto in German.

Thus, on the basis of the textual analysis of the Pāli Canon we can draw the following conclusions:

1. Until the 1st century A.D., i.e. at the time, when the Pāli Canon was established in its present form, the Nyāya Sütra was not written yet and the Nyāya School of Hindu philosophy did not exist. Reasons: (i) there are no references to this school at all; (ii) the term nyāya (ñaya) is used in the meaning of the method of Buddhists distinguishing them from non-Buddhists; (iii) in the Milindapañha, the most logical book of early Pāli literature there are logical ideas which are more archaic than the ideas of the Nyāya Sütra (the requirement of illustration is simpler in the Milindapañha and there are only two sources of knowledge: paccakkha ('evidence') and anumāna ('inference')).

2. At the time of the early suttas of the Pāli Canon, such as the Kālamma Sutta, the Sutta Nipāta, the Jātaka, and the Mahāvagga there was an art of debates (the so-called proto-logic) with the following two aspects of logical reasoning which were preserved later in Hindu logic, as well: (i) naya or defining premises for inferring; (ii) hetu or defining reasons or conditions for inferring.

3. In the early suttas of the Pāli Canon all the attitudes towards this art of debates is rather sceptical and negative.

4. For the first time, some well-done logical syllogisms occurred in the Kathāvatthu. But this treatise also contains evident sophisms and there is no semantics for logical reasoning, i.e. there are no illustration $(u d \bar{a} h \bar{a} r a n a)$ and example $(u p a m \bar{a})$ for verifying propositions. The Kathāvatthu includes debates with possible Sautrāntikas and Vaibhāśikas (the Buddhists from Gandhāra and Kashmir). This means that this text can have appeared quite late, e.g. it can be dated to the 1st century A.D., 
and it can be written under the influence of discussions with the northern (Gandhāran) Buddhists.

5. The only book of early Pāli literature that is logical indeed in all meanings is the Milindapañha. It is an absolutely unique document, because it represents a dialogue with Menander, the king of the large empire in the North and the political leader of all Bactrian-Gandhāran Buddhists. Taking into account the fact that this book is so entirely different to any other book from the Pāli Canon, we can safely claim that it was written under a direct influence of the Greco-Buddhists or Bactrian-Gandhāran Buddhists. Reasons: (i) we can detect a strange dynamics in attitudes towards logic from negative ones in early texts to a neutral attitude in the Kathāvatthu and even to a positive attitude in the Milindapañha; (ii) the Milindapañha demonstrates a real logic that cannot be deduced from the other Pāli books even terminologically and has no analogues with the classical nyāya. So, the Milindapañha can have a non-Indian influence defined by us as the Greco-Buddhist one.

As we see, the Buddhist logic of the Milindapañha with the two sources of knowledge: paccakkha and anumāna, and with opamma as one way for verifying propositions came from the Greco-Buddhist syncretic culture that flourished in Gandhāra.

\section{Conclusions}

As a result of the structuralist analysis of logical competence in early Pāli literature, the following statements can be inferred:

1. In the Pāli Canon there was a tradition of Buddhist logic, but this tradition was weak, and the proto-logic, we can reconstruct on the basis of the Pāli texts by means of the historical reconstructive hermeneutics, can be evaluated as a predecessor of the nyāya and yogācāra logic.

2. At the time of the Pāli Canon there did not exist the nyāya philosophy known by the Nyāya Sūtra.

3. The Milindapañha, the best logical source of the Pāli Canon, can have been written under a direct influence of the Greco-Buddhists.

4. From the viewpoint of the Pāli Canon, the origin of Indian logic is connected to the community that the author of the Milindapañha belonged to, and this community was Greco-Buddhist. Therefore, we can claim that the first correct application of inference rules in the early Indian logic may be explained by a Gandhāran influence. 


\section{Acknowledgements}

I would like to express my deep gratitude to Prof. Peter Harvey for his significant suggestions for improving some aspects of my paper and to Prof. Andrey Paribok for discussing the topic of Indian philosophy and logic.

Open Access. This article is distributed under the terms of the Creative Commons Attribution 4.0 International License (http://creativecommons.org/licenses/ by/4.0/), which permits unrestricted use, distribution, and reproduction in any medium, provided you give appropriate credit to the original author(s) and the source, provide a link to the Creative Commons license, and indicate if changes were made.

Publisher's Note Springer Nature remains neutral with regard to jurisdictional claims in published maps and institutional affiliations.

\section{References}

[1] Aung, S.Z., Davids, R. (tr.): Points of Controversy or Subjects of Discourse Being a Translation of the Kathā-vatthu. Oxford University Press, London (1915)

[2] Banerjee, G.N.: Hellenism in Ancient India. Munshi Ram Manohar Lal, Delhi (1961)

[3] Beal, S.: Si-Yu-Ki. Buddhist Records of the Western World, vol. I. Paul, Trench, Trübner \& co., London (1884/1981)

[4] Beal, S.: Si-Yu-Ki. Buddhist Records of the Western World, vol. II. Paul, Trench, Trübner \& co., London (1906)

[5] Bodhi, B.: The Connected Discourses of the Buddha, vol. 1-2. Wisdom Publications, Boston (2000)

[6] Bopearachchi, O.: Indo-Greek, Indo-Scythian and Indo-Parthian Coins in the Smithsonian Institution, Washington DC (1993)

[7] Falk, H., Karashima, S.: A first century Prajñāpāramitā manuscript from Gandhāra-parivarta 1 (texts from the split collection 1). Annu. Rep. Int. Res. Inst. Adv. Buddhol. Soka Univ. 15, 19-61 (2012)

[8] Geiger, W.: The Mahavamsa, The Great Chronicle of Sri Lanka. Composed in the late 5th or early 6th Century CE, by Ven. Mahanama Thera. Asian Educational Services (1912/1996)

[9] Hoover, O.D.: Handbook of Coins of Baktria and Ancient India. Classical Numismatic Group, London (2013)

[10] Horner, I.B.: Milinda's Questions, vol. 1-2. Luzac \& Company Ltd., London (1969)

[11] Jayatilleke, K.N.: Early Buddhist Theory of Knowledge. George Allen \& Unwin Ltd., London (1963)

[12] Jongeward, D., Cribb, J., Donovan, P.: Kushan, Kushano-Sasanian, and Kidarite Coins: a Catalogue of Coins from the American Numismatic Society. The American Numismatic Society, New York (2015)

[13] Karttunen, K.: Yonas and Yavanas in Indian Literature. Studia Orientalia, vol. 116. Finnish Oriental Society, Helsinki (2015)

[14] Lahiri, A.N.: Corpus of Indo-Greek Coins. Calcutta (1965) 
[15] Levi, S.: Notes sur les indo-scythes. Journal Asialique, pp. 444-484. Levi's article is translated in: Philips, W.R. 1903. 'Notes on the Indo-Scythians'. Indian Antiquary 32, 381-389 (1896)

[16] Mill, L.K.: Sutta Nipāta, Smaller Discourse on Quarrelling. SuttaCentral (2015)

[17] Mitchiner, M.: Indo-Greek and Indo-Scythian Coinage. London (1975-1976)

[18] Mukherjee, B.N.: The great Kushana testament. Indian Mus. Bull. 30, 1-105 (1995)

[19] Nārada, U., Kumārābhivamsa, U. (tr.): The Sixth Book of The Abhidhamma Pițaka. The Book on Pairs (Yamaka), vol. 1. Malaysia (1998)

[20] Olivelle, P.: Manu's Code of Law. Oxford University Press, Oxford (2006)

[21] Pingree, D.: Jyotihssāastra. In: Gonda, J. (ed.) A History of Indian Literature, Fasc. 4, vol. VI. Otto Harrassowitz, Wiesbaden (1981)

[22] Pingree, D.: The Yavanajātaka of Sphujidhvaja. 2 vols. Harvard Oriental Series 48 (1978)

[23] Potter, K.H. (ed.): Encyclopedia of Indian Philosophies. Volume II: Indian Metaphysics and Epistemology: The Tradition of Nyāya-Vaiśesika up to Gangeśa. Princeton University Press, Princeton (1977)

[24] Rapin, C.: La Trésorerie du palais hellénistique d'Aï Khanoum. L'apogée et la chute du royaume grec de Bactriane (Fouilles d'Aï Khanoum VIII, Mémoires de la Délégation archéologique française en Afghanistan 33), Paris, De Boccard. Chapitre XII sur les textes littéraires: pp. 115-130. Sur le papyrus philosophique: pp. 115-121, dessins pl. 52, photographie couleur pl. 125. Bibliographie sur les textes littéraires d'Aï Khanoum: p. 387 (1992)

[25] Rea, J.R., Senior, R.C., Hollis, A.S.: A tax receipt from Hellenistic Bactria. Zeitschrift für Papyrologie und Epigraphik 104, 261-280 (1994)

[26] Ronkin, N.: Early Buddhist Metaphysics. The Making of a Philosophical Tradition. Routledge Curzon, London (2005)

[27] Salomon, R.: The Macedonian Month Xandikos in Gandhāran Inscriptions. Stud. Orient. 110, 165-170 (2011)

[28] Schlosser, A.: On the Bodhisattva Path in Gandhāra Edition of Fragment 4 and 11 from the Bajaur Collection of Kharoșthī Manuscripts. In: Zur Erlangung des Doktorgrades eingereicht am Fachbereich Geschichts- und Kulturwissenschaften der Freien Universität Berlin im Dezember 2013. Überarbeitete Fassung (2016)

[29] Sear, D.: Greek Coins and Their Values, Volume 2, Asia and Africa. Seaby, London (1979)

[30] Senart, É.: The Inscriptions in the caves at Nasik. Epigr. Indica Rec. Archaeol. Surv. India 8, 59-96 (1905-1906)

[31] Sharma, P.: Caraka-saṃitā: Agniveśa's treatise refined and annotated by Caraka and redacted by Dṛdhabala: text with English translation, vol. 1. Chaukhambha Orientalia, Varanasi (2014)

[32] Shastri, J.L. (ed.): Shastri Mānava-Dharmaśāstra. Manusmṛti, With the Sanskrit Commentary Manvartha-Muktāvalī of Kullūka Bhatṭa. Delhi (1983)

[33] Shrava, S.: The Dated Kushāṇa Inscriptions. New Delhi (1993)

[34] Sims Williams, N., Cribb, J.: A new Bactrian inscription of Kanishka the great. Silk Road Art Archaeol. 4, 75-142 (1996) 
[35] Sims Williams, N.: Bactrian Documents from Northern Afghanistan I: Legal and Economic Documents. Oxford University Press, Oxford (2001)

[36] Sims-Williams, N.: Bactrian Documents from Northern Afghanistan II: Letters and Buddhist Texts. The Nour Foundation, London (2007)

[37] Swamy, M.C. (tr.): The Dathavansa or, The History of the Tooth-Relic Gotama Buddha. Trübner \& co., London (1874)

[38] Tarn, W.W.: The Greeks in Bactria and India. Cambridge University Press, Cambridge (1951)

[39] Thera, N.: Salha Sutta: To Salha. Buddhist Publication Society, Kandy (2013)

[40] Thera, S. (tr.): Kālāma Sutta. The Buddha's Charter of Free Inquiry. The Wheel Publication No. 8. Buddhist Publication Society, Kandy Sri Lanka (1981)

[41] Tversky, A., Kahneman, D.: Judgments under uncertainty: heuristics and biases. Science 185(4157), 1124-1131 (1974)

[42] Vats, M.S.: Unpublished votive inscriptions in the Chaitya Cave at Karle, Epigraphia Indica and Record of the Archaeological Survey of India 18, 325329 (1925-1926)

[43] Vidyabhusana, S.C.: A History of Indian Logic: Ancient, Mediaeval, and Modern Schools. Motilal Banarsidass, Delhi (1921)

[44] Watanabe, F.: Philosophy and its Development in the Nikayas and Abhidhamma. Motilal Banarsidass, Delhi (1983)

Andrew Schumann

Department of Cognitive Science and Intelligent Systems

University of Information Technology and Management in Rzeszow

Sucharskiego 2

35-225 Rzeszow

Poland

e-mail: andrew.schumann@gmail.com

Received: February 7, 2019.

Accepted: June 17, 2019. 